\title{
Yukarı Karabağ Probleminin Tarihi, Felsefi, Siyasi ve İdeolojik Açıdan Değerlendirilmesi ${ }^{1}$
}

\author{
Evaluating the Upper Karabakh Problem from a Historical, Philosophial, Political and Ideologial \\ Perspective
}

\author{
Faiq ELEKBERLi \\ Doç. Dr., Azerbaycan Milli Bilimler Akademisi, \\ Felsefe ve Sosyoloji Enstitüsü Bölümü, \\ faikalekperov@mail.ru \\ https://orcid.org/0000-0002-8865-568X
}

Makale Başvuru Tarihi: 13.12.2020

Makale Kabul Tarihi: 31.12.2020

Makale Türü: Araştırma Makalesi

\section{ÖZET}

Yukarl Karabă̆ sorununun tarihsel kökleri en az iki veya üç yüzyıl öncesine dayanıyor. Çarlık Rusya'sının Kafkasya'yı işgali, en azından I. Petro döneminde, kısa ömürlü işgal Safevi generali Nadirgulu han tarafindan sona erdirildiğinde başladl. Ancak I. Petro ile başlayan bu süreç, daha sonra Catherine II

Anahtar

Kelimeler:

Karabă̆,

Azerbaycan,

Ermenistan,

Türkiye,

Rusya,

Keywords:

Karabakh,

Azerbaijan,

Armenia,

Turkey,

Russia, döneminde devam ettirilmeye çalışıldı. Böylece 18. yüzyılda Çarlık Rusyası, Karabă̆ dâhil Kafkasya'yı da içine alan Kuzey Azerbaycan hanlıklarını ekonomik olarak bağımlı hale getirmeye çalıştı. Ancak, özellikle Karabağ'ın Çarlık Rusya'sı tarafindan Kuzey Azerbaycan'ı işgali, özellikle 1805 Kurekçay Antlaşması ile 19. yüzyılın başlarında resmiyet kazandı. Gacar devleti, Kuzey Azerbaycan da dâhil olmak üzere Güney Kafkasya'nın Çarlık Rusyası tarafindan işgalini önlemek için kuzey imparatorluğuyla iki kez savaş açtı. Ancak Gacarlar her iki savaşta da 1804-1813 ve 1826-1828'de yenildi. Gülustan ve Türkmençay Antlaşmalarının bir sonucu olarak, Gacarlar sadece Karabağ'ı veya Kuzey Azerbaycan'ı değil, tüm Güney Kafkasya'yı Çarlık Rusya'nın işgali altında bırakmak zorunda kaldı. Çarlık Rusyası, Ermenileri Kuzey Azerbaycan'a özellikle Karabă̆ topraklarına yerleştirmeye başladı ve hatta 1828 Türkmençay Antlaşması'ndan kısa bir süre sonra bir Ermeni vilayeti kurdu. Kisa süre sonra vilayeti feshetmek zorunda kalan kuzey ülkesi her durumda Karabă̆ sorununun temelini atmayı başardı. Karabă̆ sorunu, 28 Mayıs 1918'de Azerbaycan Cumhuriyeti'nin kurulması sırasında ortaya çıkt ve bu sorun Azerbaycan'ın Sovyet Rusya tarafindan işgalinden sonra da devam etti. 1923 yılında Moskova'nın desteğiyle Dağlık Karabağ Özerk Bölgesi'ni kurmayı başaran Ermeniler, Sovyet döneminde defalarca Dă̆lık Karabağ'ı Ermenistan ile birleştirmeye çalıştılar.

\begin{abstract}
The historical roots of the Nagorno-Karabakh problem go back at least two or three centuries. Tsarist Russia's invasion of the Caucasus began at least during the reign of Peter I, when the short-lived occupation was ended by the general of the Safavids, Nadirgulu khan. However, this process, which began with Peter I, was later attempted to continue during the reign of Catherine II. Thus, in the 18th century, Tsarist Russia tried to make the North Azerbaijani khanates, which included the Caucasus, including Karabakh, economically dependent. However, the occupation of northern Azerbaijan, especially Karabakh by Tsarist Russia, became official in the early 19th century, specifically with the 1805 Kurakchay Treaty. To prevent the occupation of the South Caucasus, including North Azerbaijan by Tsarist Russia, the Gajar state twice waged war with the northern empire. However, the Gajars were defeated in both wars, between 1804-1813 and 1826-1828. As a result of the Gulustan and Turkmenchay agreements, the Gajars were forced to leave not only Karabakh or Northern Azerbaijan, but the entire South Caucasus under the occupation of Tsarist Russia. Tsarist Russia began to settle Armenians in Northern Azerbaijan, especially in the territory of Karabakh, and even shortly after the Treaty of Turkmenchay in 1828, it created an Armenian province. Shortly afterwards, the northern country, which was forced to abolish the province, managed to lay the groundwork for the Karabakh problem in all cases. The Karabakh problem arose during the establishment of the Republic of Azerbaijan on May 28, 1918, and this issue continued even after the occupation of Azerbaijan by Soviet Russia. The Armenians, who managed to create the Nagorno-Karabakh Autonomous Region in 1923 with the support of Moscow, repeatedly tried to unite Nagorno-Karabakh with Armenia during the Soviet era.
\end{abstract}

1 Bu makale, İkinci Karabağ Savaşı'nda, başta yeğenim Rashad ALAKBAROV olmak üzere vatan savunmasında canlarını feda eden tüm (2783) şehitlerimizin aziz hatıralarına ithaf edilmiştir. Ruhları şâd olsun. 


\section{GIRISS}

Kafkas halkları arasında yeni çatışma alanlarının oluşması, 18. yüzyılın ikinci yarısında Kuzey Kafkasya'nın Çarlık Rusya'sı ve ardından Güney Kafkasya tarafından işgal edilmesinden sonra ortaya çıkmıştır. Bu yüzyılda, Kafkasya'da (özellikle Güney Kafkasya'da) Safeviler ve Osmanlıların zayıflamasıyla birlikte Rusya'nın hızlı yükselişi söz konusu olmuştur. Bu iki devletin siyasi ve askeri anlamda zayıflaması ile birlikte Rusya'nın dünyadaki konumunun güçlenmesi söz konusu olmuş ve bu coğrafya için yeni bir dönem başlamıştır. 18. yüzyılda özellikle Safevilerin düşüşü ve ardından Afşarların başarısızlığı gibi önemli değişiklikler, tüm Kafkas halklarının kaderinde önemli bir rol oynamış ve her millet bu değişiklikleri kendi ulusal çıkarları için kullanmaya çalışmışlardır.

18. yüzyılda Kafkasya'da Safeviler güç kaybetmesi başta olmak üzere yaşanan önemli değişikliklerden dolayı en çok kaybeden taraf Müslümanlar olmuştur. Afşarların başarısızlığı ve Osmanlı İmparatorluğu'nun zayıflaması sonucu (Nasibli, 2013:78-79), en çok kazanan taraf ta Hristiyan Ermenilerdir. Her halükarda Osmanlı İmparatorluğu'nun bir Müslüman-Türk devleti olarak zayıflaması, Safevilerin tarih sahnesinden silinmesi ve Afşarların başarısızlığa uğraması, başta Müslüman Türkler olmak üzere Kafkasya'nın tüm Müslüman halkları için büyük bir yıkım olmuştur (Afşar, 2015:4).

Nadir Şah Afşarın trajik suikastının ardından ortaya çıkan Azerbaycan Türk hanlıklarının çoğu, merkezi devlet fikrini canlandırmak yerine birbirleriyle savaşarak merkezden kaçma eğiliminde olmuşlardır. Bu açıdan Kuzey Azerbaycan Türk Hanlarının çoğu, birleşik bir Azerbaycan fikrinden ve bu kapsamda Gacar Türk devleti için savaşan Ağa Muhammed Şah Gacar ile Abbas Mirza'nın çevresinde birleşmeyi reddettiler. Bu anlamda Nadir Şah Afşar'ın fikirlerini sürdürmeyi tercih etmişlerdir. Ağa Muhammed Şah, Tebriz'e boyun eğmek istemeyen Kuzey Azerbaycan Türk Hanlıklarını (Karabağ, Quba, Şeki, Şamahı vb.) defalarca bu hususta uyarmış ve onları Gacarlar ve birleşik Azerbaycan çevresinde yeniden birleşmeye çağırmıştır. Ancak kuzey hanlıklarından sadece Gence ve Bakü hanları, birleşik Azerbaycan fikrini desteklemiştir. Diğer hanlıklar, bağımsızlıklarını Çarlık Rusyası ile Gacarlar arasında diplomatik manevra yaparak sürdürmeyi hedeflemişlerdir. Bu tercihleri sonucunda zaman zaman Moskova'nın yalnız vasalları haline gelmiş ve daha sonra ise tamamen sömürgeleşmiştirler.

Çarlık Rusya'sı Güney Kafkasya'yı işgal planını (1801-1828) tamamladıktan sonra, Azerbaycan toprakları pahasına burada bir Ermeni vilayeti oluşturmak istemiştir. Bu bağlamda Ermeni meselesini gündeme getirmiş ve Dağlık Karabağ sorununun olumsuz temellerini atmıştır. Çarlık Rusya'sı ve diğer Hristiyan devletler (İngiltere, Fransa vb.) sayesinde Ermeni sorunu ve buna paralel Dağlık Karabağ sorunu ortaya çıkmıştır. Bu sorun yirminci yüzyılın başlarında yeni bir aşamaya geçmiştir. Her halükarda Rusya ve diğer hristiyan devletlerin ortak bloğu sonucunda yirminci yüzyılın başlarında (1905-1906) Azerbaycan'da Ermeni-Müslüman çatışması hız kazanmış, ardından da 1918 yılı Mart katliamları ile Dağlık Karabağ Özerk Bölgesi'nin kurulması (1923) olayları gerçekleşmiştir.

\section{GÜNEY KAFKASYA'NIN ÇARLIK RUSYA'SI TARAFINDAN IŞGALI ÖNCESINDE AZERBAYCAN TÜRK HANLIKLARI VE GACARLAR: KARABAĞ HANLIĞININ ÇİFTE OYUNLARI}

18. yüzyılın başında Safevilerin zayıflaması ile birlikte Çarlık Rusyası, Güney Kafkasya dâhil tüm Kafkasya'yı işgal etme politikasından vaz geçerek, yeni kurulan Azerbaycan Türk Hanlıkları arasındaki birlikteliği bozmak, bu hanlıkların Osmanlı ve Gacarlara karşı kışkırtmak, sonrasında da kendisini bir "koruyucu" olarak göstermeye yönelik politikaları hayata geçirmeye başlamıştır (Azerbaycan Tarihi, 2007a:465).

Çarlık Rusya'sı, 18. yüzyılın ikinci yarısında ortaya çıkan Kuzey Azerbaycan'ın Türk hanlıklarını askeri güç yerine ahlaki ve psikolojik bir strateji ile "böl ve yönet" politikasını uygulayarak boyun eğdirmeye çalışmıştır. Bu nedenle Rusya, Güney Kafkasya'daki ilk saldırıdan/savaştan (1720'ler) ciddi sonuçlar elde etmiştir

18. yüzyılın ikinci yarısında Rusya, bazı Türk hanlıklarına, halk nezdinde saygınlığı olan din adamlarına ve bazı önde gelen kanaat önderlerine (aydınlara) hediyeler göndermiş, çocuklarını ile diğer bazı akrabalarını Rusya'ya davet etmiş, bu bağlamda da azınlık haldeki etnik gruplarla işbirliği yaparak başka bir saldırı politikasının önünü açmışır (Azerbaycan Tarihi, 2007a:464). En önemlisi ise Çarlık Rus ideologları, Kuzey Azerbaycan Türk Hanlıkları'nı Gacarlar ve Osmanlılardan olabildiğince uzaklaştırmaya çalışırken, bu hanlıkların bağımsız olamayacakları tezini ileri sürmüşlerdir. Aynı zamanda tek bir devlet çatısı altında birleşememeleri için aralarındaki düşmanlıkları daha çok artırmaya çalışmışlardır. 
Çarlık Rusya'sının ideologları, Afşarlardan sonra eski Safevilerin topraklarında yeni bir devlet kurmak isteyen Gacarlar ile Kuzey Azerbaycan Türk hanlıkları arasındaki ilişkilere her zaman dikkat etmişlerdir. Bu noktada Güney Kafkasya'nın ve Kuzey Azerbaycan'ın yeni kurulmuş Türk Devletlerinin sınırları içinde kalmasına engel olmuşlardır.

Nadir Şah Afşar'ın Çarlık Rusya'sına karşı savaşının şartları ile Ağa Muhammed Şah Gacar'ın Çarlık Rusya'sına karşı olan savaşının şartları aynı olmamıştır. Ağa Muhammet Şah Gacar, Kuzey Azerbaycan Türk hanlıklarını bir araya getirme isteği doğrultusunda Çarlık Rusya'sına karşı savaşmıştır. Gacar Türk Devleti’nin temellerini 1780'lerde atan Ağa Muhammed Şah Gacar, "hamiler" bulan bir dizi "bağımsız" hanlık ve Güney Kafkasya'yı yeni taktiklerle işgal etmek isteyen Rusya ile karşı karşıya kalmıştır. Ağa Muhammed Şah Gacar için her iki hedefin de üstesinden gelmek ve Kuzey Azerbaycan da dahil olmak üzere Güney Kafkasya'yı yeni devlete entegre etmek hayati önem taşımaktaydı. Ancak, bu hanlıkların koruyucusu rolüne soyunan, gerçekte ise bu hanlıkların potansiyel bir işgalcisi olan Rusya'yı bu birleşmeye ikna etmek oldukça zordu. Bu açıdan bakıldığında, Ağa Muhammed Şah'ın Güney Kafkasya'ya ilk askeri harekâtından (1795) kısa bir süre sonra Çarlık Rusya'sının adımlar atması tesadüfî olmamıştır. Çar I. Petro'dan sonra Kuzey Azerbaycan da dâhil olmak üzere Güney Kafkasya'nın ikinci işgalini yöneten General Valerian Zubov liderliğindeki büyük bir Rus-Kazak ordusu Nisan 1796'da Guba, Derbent, Gence, Şamahı ve Bakü şehirlerini işgal etmiştir.

Çarlık Rusyası'nın bu askeri harekâtı sırasında, daha önce Gacarlara destek veren üç hanlıktan sadece Quba hanlığının hanı Şeyh Ali Han, sonuna kadar Gacar birlikleri ile Ruslara karşı savaşmıştır. Gacarlara birleşme sözü veren Gence, Şeki, Karabağ, Bakü ve Şamahı hanlıkları ise esas olarak bağımsızlıklarını Çarlık Rusyası'nın koruması altında sürdürmeyi umdukları için Rus birliklerine ciddi bir direniş göstermeden teslim olmuşlardır (Bakhanov, 2001:209).

Karabă̆ hanlığı, Rusya'nın himayesini ilk kabul eden hanlık olmuştur. Diğer hanlıklar da bu durumun etkisi altında kalarak Kuzey İmparatorluğu'na (Zubov'a) teslim olmaya hazır olduklarını beyan eden mektuplar yazmışlardır. Mirza Camal Cavanşir bu hususta (Karabağname, 2006a:64,141);

\section{"İbrahim han oğlunu büyük generalin (General V.Zubovun) yanına göndereceğini duyan çevresindeki hanlardan Taliş hanı Mir Mustafa Han, Şirvan Mustafa Han, Cevat Han ve hatta Erivan, Nahçıvan, Hoy ve Karabağ hanları rahmetli İbrahim Han'a elçi göndererek İbrahim han'ın tavsiyelerine uymayacakların beyan etmşlerdir. Bize Rus devletine itaat etmemizi tavsiye ettiği için, merhametli Rus çarına içten itaatini de kabul edeceğiz."}

Bilgilerini aktarmaktadır. Hanlıkların çoğunun böylesine bir tutum sergilemesi Gacarlar üzerinde çok olumsuz bir etki oluşturmuştur. Ağa Muhammed Şah bu duruma itiraz ederek hanların Rus askerlerine karş1 savaşmalarını istemiştir. Ancak bunun hiçbir somut sonucu olmamıştır (Azerbaycan Tarihi, 2007a:473). II. Yekaterina'nın 6 Kasım 1796'daki ani ölümü ve I. Pavel'in tahta geçmesi sahadaki fiili durumu değiştirmiştir. Pavel tahta çıkar çıkmaz Rus birliklerinin Güney Kafkasya'dan çekilmesini emretmiştir. Bunun sonucunda da Çarlığın Güney Kafkasya'yı işgal etme planı uygulanamamıştır.

Ağa Muhammed Şah Gacar, 1797 baharında, Çarlık Rusya'sındaki hükümdar değişikliğinin oluşturduğu boşluktan faydalanarak Kuzey Azerbaycan da dâhil olmak üzere Güney Kafkasya'yı tamamen ele geçirmek için ikinci bir askeri harekât düzenlemiştir. Güney Kafkasya'da bir askeri harekâta başlamadan önce, Ağa Muhammed Şah Gacar, Gacarlarla tekrar birleşmek istemeyen hanlıklara kararnameler göndermiştir. Aynı zamanda Ağa Muhammed Şah Gacar, ilk seferde alamadığı Karabağ hanlığının merkezi Şuşa'yı ele geçirdiği takdirde sadece Karabağ hanlığını değil diğer hanlıkları da birleştireceğini öngörüyordu.

Karabağ hanlığının, ilk seferde olduğu gibi, ikinci seferde de Gacarlara karşı dirençli olmasının temel nedeni, sahip olduğu stratejik konumudur. Ne yazık ki Karabăg hanı İbrahimhalil Han, "hamisi" Rusya'nın etkisi altında kalarak, isteyerek veya istemeyerek, Ağa Muhammed Şah Gacar ile ortak bir dil bulmak yerine, davete icabet etmeyerek savaş yapma yolunu seçmiştir.

Ancak bu sefer Ağa Muhammed Şah Gacar, küçük bir grupla Balaken veya Şeki'ye kaçmış ve aslında ona güvenenlere ezici bir darbe indirmiştir. Buradan hareketlr modern Azerbaycan tarih kitaplarında İbrahimhalil han'ın kahraman olarak ve Ağa Muhammed Şah Gacar'ın zalim, saldırgan bir düşman olarak tanımlanmaktadır. Bu gruplandırma, Sovyet-Rus tarih yazımı geleneğinin bir devamıdır (Azerbaycan Tarihi, 2007a:476-477).

Şuşa'nın ele geçirilmesinden sonra Ağa Muhammed Şah Gacar, Kuzey Azerbaycan'ın Türk hanlarına onun yanına gelmelerini veya en sevdiklerini kendisine rehin göndermesini talep etmiş, birçok han da buna uymuştur. Muhammed Şah Gacar, Kuzey Azerbaycan'ın işgali sırasında Rus birliklerine direnmeyen hanların bir daha ihanete uğramamak koşuluyla çoğunu affetmiş ve bu hanları haklı olarak sert bir şekilde kınamıştır. Böylelikle, 
Kuzey Azerbaycan'da gücünü büyük ölçüde geri getiren Ağa Muhammed Şah Gacar, Kartli-Kaheti'yi ziyarete hazırlanmaya başlamıştır.

4 Temmuz 1797'de Azerbaycan Türk tarihi açısından önemli bir gelişme yaşanarak Ağa Muhammed Şah Gacar suikaste kurban gitmiştir (Azerbaycan Tarihi, 2007a:479). "Karabağname" yazarlarından Ahmed Bey Cavanshir konuyla ilgili olarak; Muhammed Bey ile Sadık Han Şegaginin bu ölümde birlikte hareket ettiklerini dolaylı olarak teyit ettiklerini ifade etmektedir (Karabağname, 2006a:192). Yazar, zamanın belirli koşullarında Ağa Muhammed Şah Gacar'a yönelik suikast girişiminin ana organizatörünün adını vermemiş olsa da, bugünün Azerbaycan Türk tarihçileri, suikastin faillerinin Sadık Han Şagağı ve Muhammed Bey Batmangilinci olduğunu kabul etmelidirler (Hasanzadeh, 2007:113).

18. yüzyıl Azerbaycan Türk tarihinde 1747 ve 1797 y1lları iki tarihi kırılma noktalarıdır. 1747'de Afşar devletinin kurucusu Nadir Şah Afşar'ın suikast ile öldürülmesi ve sonrasında 1797'de Ağa Muhammed Şah'ın Şuşa'da trajik bir şekilde öldürülmesi bu iki önemli kırılma noktasıdır. Ağa Muhammet Şah'ın ölümü Azerbaycan Türklerinin bütünlüğüne ciddi bir darbe indirmiş ve Karabağ sorununun temelini atmıştır. Bunun sonucunda da Kuzey Azerbaycan'nın kaybedilmesiyle 1925 yılında Gacarların çöküşü başlamıştır.

Her halükarda, bunun Ağa Muhammed Şah Gacar'ın kuzey Azerbaycan'ı kontrol altına alıp, Tiflis'e (Gürcistan) ziyaret için hazırlandığı bir dönemde gerçekleşmiş olması tesadüf olarak kabul edilemez. Çünkü sadece Ağa Muhammed Şah'ın öldürülmesi, Kuzey Azerbaycan da dâhil olmak üzere Güney Kafkasya'nın Gacarlarla birleşmesine son verebilirdi. Bunu çok iyi anlayan Çarlık Rusyası, yaklaşan tehlikeyi önlemek için, Sadık han Şegigi'yi Ağa Muhammed Şah Gacar'ın öldürülmesinden sonra Gacarların tahtına oturmayı, Muhammed Beyi ise Karabağ hanlığının Hanı yapmayı vaat etmiştir.

Ağa Muhammed Şah Gacar'ın öldürülmesinin ardından suikast faillerinin attı̆ğ adımlar ve Rusya'nın bunlara yönelik önleyici muamelesi bunu doğrulamaktadır. Moskova'nın sinsi planı ile Ağa Muhammed Şah Gacar'ın öldürülmesinden hemen sonra Sadık Han ve Muhammed Bey'in kısa bir süre için sırasıyla "Şah" ve "Han" olarak davranmaları tesadüf olmamıştır. Ağa Muhammed Şah Gacar'ın öldürülmesine rağmen, "birkaç engelle" İbrahimhalil Han'ın Karabağ'a üç ay boyunca gidemeyip, Balaken'de kalmasının ve Karabağ hanı olarak davranışının sebebi Çarlık Rusyası olmuştur (Karabağ Mektupları, 2006:164). Bu nedenle Çarlık Rusyası için İbrahimhalil Han'ın Ruslar tarafından gücendirilmesi ve Gacarlara doğru eğilmesi artık önemli değildi. Karabağ hanlığı ile Gacarlar arasındaki ilişkilerin, Rusya ile olan kızgınlık zeminine rağmen, çarlık ideologlarına göre uzun sürmeyecek ve bu ilişkiler daha da isınacaktır. Bunun nedeni ise, Karabağ Hanlığı'nın daha önce Çarlık Rusya'sının yanında yer alması ve Gacarlara karşı en aktif düşmanlık politikasını izleyen hanlıklardan biri olmasidır.

Çarlık Rusyası, kısa süre sonra tekrar Ruslara dönen İbrahim Halil han gibi kendilerine sadık bir hanı tamamen görmezden gelmedi. Böylelikle İbrahimhalil Han, daha önce General Gudovich ve General Zubov aracılığıyla Rusya'ya itaat ettiği gibi bu olaylardan sonra da Rus generalleri Kavalevsky ve Sisianov ile ilişkilerini sürdürerek bağl1lığını ortaya koymuştur (Karabağ Mektupları, 2006:149).

Ağa Muhammed Şah'ın öldürülmesinden sonraki tüm süreçler Çarlık Rusyası'nın planına göre gelişmiştir. 1797 sonbaharında Fatali Şah Güney Kafkasya'da bir askeri harekât başlatmıştır. Ancak Rus birliklerinin oraya hareket ettiği haberini alınca geri çekilmiştir (Azerbaycan Tarihi, 2007a:480). Fatali Şah'ın Kuzey Azerbaycan'daki askeri harekâtını durdurmakla ciddi bir hata yaptığı düşünülmektedir. Askerî seferlerine Ağa Muhammed Şah kadar ssrarla devam etseydi, Gacarlar ile birleşmeye isteksiz olan Kuzey Azerbaycan Türk Hanlarının direnişini kıracak ve Çarlık Rusya'nın yeniden birleşmesine ciddi bir darbe indirmiş olacaktı. Ağa Muhammed Şah Gacar'dan farklı olarak, Fatali Şah'ın ilk günlerde (1797-1803) Kuzey Azerbaycan meselesindeki tereddütlü ve kararsız hareketleri Çarlık Rusya'sının çalışmalarını büyük ölçüde kolaylaştırmıştır.

Özellikle Fatali Şah Gacar (1797-1834), Karabağ Hanlığı da dâhil olmak üzere birçok hanlıkla ilişki kurma şansı bulduğu bir dönemde bundan tam olarak yararlanamamıştır. Fatali Şah Gacar, özellikle Azerbaycan'ın başkenti Tebriz'de yaşayan Gacar Veliaht Prensi Abbas Mirza'nın zekice ve kararlı görüşleri nedeniyle daha sonra Rusya'ya karşı aktif bir eylemde bulunmuştur. Ama bu, çok geç kalınmış bir hareket olmuştur. Çünkü Gacarların, zamanında yapamadığı bu çalışmayı Çarlık Rusyası (Çar I. Aleksandır) doğru bir şekilde değerlendirerek, 1801'den itibaren Güney Kafkasya'yı işgal politikası izlemeye başlamıştır (Azerbaycan Tarihi, 2007:15). 


\section{KARABAĞ HANLIĞI'NIN ÇARLIK RUSYA'NIN KORUMASI ALTINA GİRMESİ: "KÜRAKÇAY ANLAŞMASI"}

Kuzey Azerbaycan Türk Hanlıkları'nın (Karabağ, Gence, Quba, Şeki, Şamahı, Erivan vb.) XIX. yüzyılın ilk yıllarından itibaren Çarlığın kışkırtmaları nedeniyle birlik gösterememesi ya da Gacarların çatısı altında birleşme fikrine karşı çıkmaları ve Ağa Muhammed Şah Gacar'ın Şuşa'da Çarlık Rusyası tarafindan düzenlenen (1797) bir suikast sonucu ölümü Karabağ'ın bu süreçten sonraki kaderinde belirleyici rol oynamıştır. Özellikle Şuşa'da Ağa Muhammed Şah Gacar'ın öldürülmesiyle birlikte, Safeviler'den sonra Nadir Şah Afşar'ın başlattığı tek bir Türk devleti etrafında birleşme fikri bir kez daha yarım kalmıştır.

18. yüzyılda yaşanan iki trajik olaydan, iki kırılma noktasından sonra, 19. yüzyılın başlarında, Kuzey Azerbaycan ve Güney Kafkasya'nın Gacarlar tarafından fethi ihtimali azalmış, Çarlık Rusya'nın bölgeyi işgal etme tehdidi ise hızla artmıştır. Bunun açık bir örneği, 1801 yılında, Kartli-Kaheti krallığının işgali üzerine Çarlık bildirgesinin ilan edilmesiyle, Çarlık Rusya'sının Güney Kafkasya'yı üçüncü kez işgale başlamış olmasıdır. Böylece, 19. yüzyılın ilk yılından itibaren "korumacı (himayeci)" Çarlık Rusya'sı, tekrar işgalci Çarlık Rusya'sı haline gelmiştir. 26 Aralık 1802'de bazı kuzey Azerbaycan Hanlıkları'nı (Guba, Lenkeran) ve Kafkasya'nın diğer bağımsız hükümdarlarını (Tabasaran, Garagaytağ, Terki) anlaşma imzalamaya zorlamıştır. Gacarlardan gelen ciddi itirazlara rağmen, Georgievsky Antlaşmasına göre bağımsız hanlıkların veya sultanların kendi istekleri üzerine sözde bağımsızlıkları için Rus himayesini kabul etmeleri ve aynı zamanda Gacarlarla yaklaşan savaşta Rusların yanında yer almak zorunlulukları bulunmaktaydı.

Azerbaycanlı tarihçiler, bu hanlıkların çoğunun şimdiye kadar Georgiyevsky (1802) ve Kürekçay (1805) gibi anlaşmaları imzalamalarını haklı bir zorunluluk olarak göstermelerini genel olarak Türkiye ve "İran" tehdidine bağlarlar. Ancak bu yaklaşımların kabul edilebilir bir geçerliliği yoktur. Çünkü bu coğrafyadaki işgalci güç doğrudan doğruya Rusya'dır (Azerbaycan tarih, 2007b:15-16). Günümüze kadar bu coğrafyada gelişen tüm siyasal olaylar bu olguyu ispatlamaktadır. Bu anlaşmaların imzalanması ile birlikte saldırganlık ve işgal niyetleri için yasal statü kazandırmaya çalışan Rusya 1803 yılında Car-Balaken topluluğunu ve Ilısu Sultanlığı'nı; 1804'ün başlarında da Gence Hanlığı'nı kanlı savaşlardan sonra işgal etmiştir.

Kuzey Azerbaycan tarihi, Rusya-Gacar savaşları (1796-1797; 1804-1813; 1826-1828) dâhil olmak üzere Gacar tarihinin özüne başka bir renk katmaya devam etmiş ve bazı konularda Sovyet tarih yazımı metodolojisi geleneğine bağlı kalmıştır. Örneğin, Azerbaycan (kuzey) tarihçileri Rus-Gacar savaşlarını "Rus-İran savaşı" olarak tanımlamaktadırlar. Ancak bu savaş bir Rus-İran savaşı değil, Gacar Devleti'nin Kuzey Azerbaycan da dâhil olmak üzere Güney Kafkasya'dan Rus birliklerinin çıkarılması için verdiği bir savaştır.

Kuzey Azerbaycan Türk Hanlarının Rus-İran savaşının kurbanları olarak tasvir edilmesi gerçeği yansıtmamaktadır. 7 ciltlik "Azerbaycan Tarihi" nin 4. cildindeki görüşler bu bağlamda gerçekleri yansıtmamaktadır. Mevcut gerçek, bazı hanlar ve küçük çevreler dışında, Kuzey Azerbaycan Türklerinin bu savaşlardaki konumu, SSCB tarih yazımı geleneğine bağlı çağdaş Azerbaycan tarihçilerinin yazılarının tam tersine (Azerbaycan Tarihi, 2007:20-21) Gacarların yanında yer almış olmaları ve diğer Azerbaycan Türkleri ile birlikte Çarlık Rusya'sına karşı savaşmış olmalarıdır. Sonuç olarak da iki değil bir yabancı gücün işgal politikasına kurban olmuş olmalarıdır. Çarlık Rusya'sının bu savaşta tek işgalci güç olduğunu kanıtlayan en önemli gerçek, Moskova'nın savaş sırasında zaman zaman hanların (İbrahimhalil han vb.) öldürülmesi emrini verirken, Gacarlarla birleşmeye itiraz edenlerin kaçarak onlara sığınırken böyle bir sorunla karşılaşmamalarıdır (Alakbarl1, 2017:251).

19. yüzyılın başlarında Gacarlar döneminde, genel olarak Azerbaycan sosyo-politik ortamına baktığımızda RusGacar savaşının (1804-1813) arifesinde, zorunlu koşullar altında önceden Rusya'ya yakınlık gösteren bazı Kuzey Azerbaycan hanlıkları (Gence, Bakü, Guba vb.) yanıldıklarını anlayarak Gacarlar'ın yanında yer almaya başlamışlardır. Ancak Karabağ hanlığı dahil diğer hanlıklar (Erivan, Şeki, Şamahı vb.) Çarlıktan uzaklaşmaya cesaret edememişlerdir.

Gence hanlığı, özellikle Cevat hanı, Kafkasya'da Çarlık Rusyası'nın işgalci ordusuna ve lideri General Sisianov'a (Ocak 1803-1804) karşı onurla savaşırken, Karabağ hanı İbrahimhalil han Rusya'nın bir tebası olma eğilimindeydi. Gacarlar, bunu önlemek için defalarca Türk Devletinin Lideri Fatali Şah İbrahimhalil Hanın yanına elçi göndermişlerdir. Rusya ile savaşta Karabağ Hanlığı'nın Gacarlarla birleşirse ona dokunulmayacağı ve her daim onun yardımcıları olacağı söylemiştir. "Buradaki amaç Allah'in eli ile oluşturulmuş, Gürcüstan ve Şirvanin esas kapısı olan Şuşa kalesi Rusya devlet birliklerinin eline geçmesin" (Karabağ Mektupları, 2006a:152). Fatali Şah'ın, İbrahimhalil han'ın Rusya'ya itaatini engellemeye çalıştığı bir dönemde (Karabağ 
Mektupları, 2006b:192) Karabağ hanı 14 Mayıs 1805'te Rusya ile tebaası adına utanç verici olarak nitelendirilecek bir Kürekçay anlaşması imzalamıştır (Karabağ Mektupları, 2006a:152). Ayrıca Karabağ Hanlı̆̆ı'nın Şeki Hanlığı'nı kışkırtması ve Rusya ile Kürekçay anlaşmasının imzalaması Gacar devleti için beklenmedik bir olay olmuştur.

İbrahim Halil Han, Kürekçay anlaşmasına rağmen, nedense Rusya'ya tam güven göstermemiştir. Özellikle Güney Kafkasya'daki Rus birliklerinin komutanı General Sisianov'un Şubat 1806'da Bakü yakınlarında Bakü hanı Hüseyngulu han ile yaptığı görüşmede öldürülmesi güvensizliği artırmış ve bu olaydan kısa bir süre sonra İbrahimhalil han, Gacarlar ile ilişkileri yeniden kurmuştur (Pakravan, 2007:21) . "Karabağname" yazarları onu İbrahim Halil Han'ın yaşlılığı ve hastalığı ile ilişkilendirmeye çalışsalar da her durumda Gacarlarla bir yakınlaşma olayı yaşanmıştır. Karabağ Hanın'ın ikili davranışı Rusya'yı rahatsız ettiği için Ruslar İbrahimhalil Hanın ölümünü emretmişlerdir (Karabağ Mektupları, 2006a:155-156).

Türk Hanlıkları üzerinde çirkin bir Rusya oyununun ortaya çıkmasından sonra Şeki, Quba, Bakü, Şamahı, Erivan gibi hanlıklar Gacar Türk devleti etrafında daha sık birleşmeye başlamışlardır. Her halükarda, Gacarlara bağlı hanlıklar halefiyetlerini sürdürürken, Çarlık Rusya'nın vasallığını kabul eden veya etmeyen tüm hanlıkların varlığının yavaş yavaş her anlamda ortadan kaldırıldığını anlamak zor olmamıştır. Bu durumda, Kuzey Azerbaycan'ın işgal altındaki topraklarında Rusya-Gacarlar savaşından (1807-1813, 1826-1828) sonraki yıllarda Çarlık Rusya'nın "böl ve yönet" politikasına karşı ulusal protestolar olmuş ve bunu gerçekleştirenler de Gacarlar'la birlikte hareket etmişlerdir (Alakbarlı, 2017:255).

\section{RUSYA-GACAR SAVAŞLARI VE KUZEY AZERBAYCAN'IN ISŞGALİNIN RESMİLEŞTİRİLMESİ}

Rus yanlısı hanların acı kaderinin yanı sıra, tek vatan, tek devlet, tek millet olarak yaşama arzusu, Gacarlar ile Kuzey Azerbaycan Türkleri arasındaki birliğin oluşmasında önemli rol oynamıştır. En azından 1796-1797 ve 1804-1813 Rusya-Gacar savaşlarında vatan, devlet ve millet fikirleri dinsel faktörle karşılaştırıldığında daha ön planda olmuştur. Ancak 1812 yılından itibaren Fatali Şah Gacar İngiltere'nin tavsiyesi üzerine Rusya'ya karşı gerçekleştirilecek savaşı kutsal bir cihad olarak ilan etmiştir (Azerbaycan Tarihi, 2007:35).

Rusya-Gacarlar savaşının dini-cihatçı özelliği İngiliz düşüncesinin bir ürünüdür. İngilizlerin buradaki asıl amac1, Rusya'yı dini mezhepçilik kisvesi altında güçlendirmek veya yenilgiye uğratmak değildir. Gacarlar üzerinden Fars taraflı (İran yönlü) Şiiliğinin yeniden canlandırılması ve Gacarların dini muhafazakârlığın ana sesinin bu yönlü olmasıdır. Farklı bir kurgudaki Rus-Gacar savaşı İngilizler için ideal bir seçenek olamazdı. 1812'de Fatali Şah Gacar, bu bağlamda din adamlarının savaşa fetva vermesini isteyerek yeni bir adım atmıştır.

Rusya-Gacarlar savaşlarının sonucu olan Gülustan (Ekim 1813) ve Türkmençay (Şubat 1828) barış antlaşmaları, aslında Azerbaycan Türkleri’nin bölgede söz sahibi olma hakkını kaybetme sürecinin başlangıcı olmuştur. Bu barış anlaşmalarına sadece Azerbaycan Türk topraklarının ve Azerbaycan Türklerinin ikiye ayrılması şeklinde bakmak doğru değildir. Devlet topraklarının bir kısmı, özellikle de yüzyıllardır yaşadığı o devleti (Gacarlar) oluşturan asıl gücün önemli bir kısmı yabancı bir imparatorluk tarafından işgal edilmişti. Böylece Safeviler ve Afşarlar döneminde Azerbaycan Türk topraklarını işgal edemeyen Çarlık Rusyası, 19. yüzyılın ilk çeyreğinde uzun savaşların sonunda Gacarları bu anlaşmaları yapmaya zorlayabilmiştir.

Rusya ile Gacarlar arasında gerçekleşen ikinci (1804-1813) ve üçüncü (1826-1828) savaşlarda Gacarların yenilgiye uğramasında aşağıdaki faktörler önemli rol oynamıştır (Elekberli, 2017:263);

1. Ağa Muhammed Şah Gacar'ın (1797) suikastı ve bu konudaki Rusya'nın faaliyeti,

2. Kuzey Azerbaycan Türk Hanlıklarının 1796-1797, 1804-1813 savaşlarındaki ikiliği, özellikle Rusya yanlısı hanlıkların (Karabağ vb.) affedilemez hataları,

3. Gacarların Rusya'ya karşı yürüttüğü savaşlarda yabancı güçlerin, özellikle İngilizlerin ikili konumu,

4. Rus-Gacar savaşının başlangıcında vatan ve millet için mücadelenin dini alana kayması,

5. Gacarlarla birleşmiş Farslar da dâhil olmak üzere İran dili konuşan halkların ikili tutumları,

6. Rusya'ya karşı yapılan savaşlarda Osmanlı-Gacar ilişkilerinin yanlış kurulması, bu güvensizlikte İngilizlerin rolü,

7. Çarlık Rusyası'nın modern askeri gücüne karşı yeni kurulan modern olmayan Gacar ordusu,

8. Çarlık Rusyası'nın Gacarlar'ın Safeviler ve Afşarlar'dan kalan eski imparatorluklar üzerine inşa etmeye çalıştıkları yeni devletle karşılaş̧ırıldığında birkaç yüzyıllık yerleşik emperyal deneyime sahip olması. 
Rusya-Gacar savaşları (1796-1797; 1804-1813; 1826-1828) ve sonuçları Gacar devletindeki tüm Türklerin, özellikle Azerbaycan Türklerinin hayatını olumsuz etkilemiş ve geleceğinde önemli bir rol oynamıştır. Maalesef bütün bunlar daha önce de belirtildiği üzere, başta 7 ciltlik Azerbaycan Tarihi olmak üzere bu konularda kaynak olma özelliği gösteren eserlere doğru yansıtılmamıştır. Yaşanan bu olaylar genel olarak sosyo-politik ve felsefi düşünce tarihine doğru bir şekilde aktarılmamıştır (Alakbarov, 2014:303-304). Bu bağlamda ifade etmek gerekir ki, "Türk (Azerbaycan) halkı tarihi" kavramı yerine "Azerbaycan Tarihi" gibi bir kavram kullanılmamalıdır. Başka bir ifade ile sadece bir coğrafi bölgenin tarihini yazdığımız ve buna göre eklektik bir tarih oluşturduğumuz sürece Nadir Şah Afşar, Ağa Muhammed Şah Gacar, Abbas Mirza ve Fatali Şah Gacar gibi tarahi karakterler Azerbaycan için yerli olmaktan çıkıp, yabancı şahsiyetlere dönüşecektir.

Çağdaş Azerbaycan tarihçileri, Rusya'nın Kuzey Azerbaycan Türk hanlıklarıyla İngilizlerin Gacarlar üzerinde barbar işgal oyunlarını ortaya çıkarmak ve aynı zamanda Gacarlar ile Kuzey Azerbaycan Türklerinin birliğini zaman zaman ifade etmek yerine, Abbas Mirze'nin önderliğinde Gacarlar ordusunun 1804-1813, 1826-1828'li yıllarda Kuzey Azerbaycan'1 Rus askerlerinden kurtarmak için gerçekleştirdikleri bütün savaş hareketlerini yağmacılık, saldırı, yıkım ve diğer taraftan da İngiliz oyuncağı olarak nitelendirmektedirler (Azerbaycan Tarihi, 2007:22-23,27,30). Azerbaycan'ın 7 ciltlik tarihinin 4. cildinin Rusya-Gacarlar savaşlarını ele alan bölümleri, Çarlık Rusya'sının Kuzey Azerbaycan'ı işgalini açıkça olmasa da haklı çıkarmaya çalışmaktadır. Bu anlamda, Rus birliklerinin Kuzey Azerbaycan'ı işgallerine basitçe "işgal" ve "sömürge niyetleri" olarak tanımlanırken, Gacar ordusunun eski Türk topraklarını yeniden ele geçirmek için yürüttüğü askeri seferleri İngiliz desteği kisvesi altında "yıkım", "yağma", "saldırganlı" olarak tanımlamaktadırlar (Azerbaycan Tarihi, 2007b:13,20,23,27,30,33,42). Rusya'nın kuzey Azerbaycan'daki işgal yürüyüşlerine gelince, "Azerbaycan Tarihi" nin 4. cildinde Rus birliklerine ait olabilecek "yağma", "yıkıcı", "küstahlık", "saldırı" gibi ifadelere rastlamamaktadır. Bu durumda, daha genel olan "işgal" kelimesini kullanmanın yanı sıra, "fetih", "boyun eğdirme", "Rusya'ya boyun eğme", "zapt etme" gibi ifadeler tercih edilmektedir (Azerbaycan Tarihi, 2007:17,14,28,29). Rusya'nın Gacarlar karşısındaki zaferlerine sempati açıkça hissedilmektedir (Azerbaycan Tarihi, 2007:27,32,34,37). Bu arada Azerbaycanlı tarihçiler sadece Gacarları değil, topraklarını Rus birliklerinden kurtarmak isteyen Kuzey Azerbaycan Türklerini de soyguncu olarak tanımlamışlardır. Onlara göre Gacarlar'la birlikte hareket eden hanların asıl görevi, köprüleri, fabrikaları ve yiyecek kaynaklarını yok eden yıkıcı gruplar oluşturmaktı (Azerbaycan Tarihi, 2007: 45). Bu hanlıklardan bazılarının Rus traftarı olduklarında hırsız, yağmacı veya gaspçı olmadıkları vurgulanır, ancak Gacarlarla birlikte Rus birliklerine karşı savaştıklarında ise hemen bu sıfatlar layık görülmektedirler. Bu da gösteriyor ki, Türklerin zihninde aşılanan "ilerici Rusya" fikri hala devam etmektedir.

Azerbaycan-Türk tarih yazımının bu döneminin ana konularından biri, Rus-Gacar savaşlarının ve sonraki süreçlerin büyük ölçüde, belki de yüzde 90'ının Rus kaynaklarına atıfta bulunarak yazılmış olmasıdır. Bununla birlikte, Rus-Gacar savaşlarıyla ilgili, özellikle yerel Türk kaynakları ile ilgili birçok başka kaynak bulunmaktadır. Bu durumda, Sovyetler Birliği'nde olduğu gibi Rus-Gacar savaşlarını esas olarak Rus kaynaklarına atıfta bulunarak değerlendirmenin oldukça yanlış olduğunu söylenebilir (History of Azerbaijan, 2007:429-430).

Tarih yeni nesillere doğru aktarılamazsa, Azerbaycan'ın bütünlüğü ve yeni bir Türk devletinin kurulması sadece sözde kalmaya devam edecektir. Bu anlamda, Azerbaycan'ın birleştirilmesinin önemli bir sonucu, günümüz neslinin Nadir Şah, Ağa Muhammed Şah, Abbas Mirza gibi şahsiyetleri doğru tanıması, sahip çıması ve onların torunları ve halefleri olduklarını bilmesidir.

\section{5. ÇARLIK RUSYASI'NIN GÖÇ PLANLARI VE SÖZDE "ERMENİ VILAYYTİ"}

Güney Kafkasya'nın ve Azerbaycan'ın kuzeyinin işgalini Türkmençay barış antlaşması ile resmileştiren Çarlık Rusyası, bölgede iktidarı korumak için 1828 ile 1850 yılları arasında etnik, dini, siyasi ve idari çıkarlarında bir dizi "reformlar" gerçekleştirmiş, bütün bunlara ulusal bir refleks eşlik etmiştir. Kuşkusuz bu konudaki en önemli mesele, Çarlık Rusya'sının yönetimde Azerbaycan Türklerine yönelik baskısının artması ve milli geleneklerine ve İslam dinine akıl almaz, ikiyüzlü yöntemlerinin kullanılmasıydı. Rusya, Kuzey Azerbaycan dâhil Kafkasya'nın işgalini tamamladıktan sonra askeri güçlerle birlikte büyük bir kurnazlık politikası uygulayarak, öncelikle hanlıkların tüm yetkilerini ellerinden almış, Karabağ, Şeki, Bakü, Şirvan vb. bölgelerdeki yönetimi ise Rus veya Hristiyan kökenli olanlara (Türk ve Müslüman olmayanlara) teslim etmiştir.

Hanlık yerine farklı bir yönetim sistemi uygulayan çarlık, 6 vilayet (Lenkeran, Şirvan, Şeki, Bakü, Karabağ, Quba), Yelizavetpol bölgesi, Car-Balaken bölgesi, Ermeni bölgesi ve iki farklı merkez (Gazah, Şemşeddil) oluşturmuştur (Azerbaycan Tarihi, 2007:100-101). 
Güney Kafkasya'da ve Kuzey Azerbaycan'da böyle bir bölünme, gelecekte imparatorluğun çıkarları doğrultusunda Hristiyan Ermeni, Hristiyan Gürcü ve mümkünse Hristiyan Rus-Alman vilayetleri (bölgeleri) yaratacak şekilde hesaplanmıştır. Her halükarda, Müslüman-Türk devletlerinin (Safeviler, Afşarlar, Osmanlılar, Gacarlar) 19. yüzyıla kadar zayıflamasından veya tamamen ortadan kalkmasından sonra, bölgedeki yeni koşullar başta Çarlık Rusya olmak üzere Rusya ve İngiltere dâhil olmak üzere daha çok Hristiyan devletlere fayda sağlamıştır. Onu güçlendirmek için herhangi bir şekilde Hristiyan nüfusun sayısını artırmak ve Hristiyan vilayetlerini buna göre oluşturmak gerekiyordu. Bu anlamda, Hristiyan Ermenilerin Güney Kafkasya'da, Çarlık Rusya'sının, özellikle bölgenin işgalinden sonra Osmanlı ve Gacarlardan yerlerinden edilen (göç eden) Ermenilerin yardımıyla Türk-Müslüman toprakları pahasına ermenilerin ruslara yaptıkları hizmetler karşılıksız kalamazdı. Bu anlamda, Türkmençay Antlaşması'nın (1828) hemen ardından, Çarlık Rusya'sının işgal altındaki Güney Kafkasya'nın bir bölümünde, yani Müslüman-Türk toprakları İrevan ve Nahçıvan'da Ermeniler için sözde bir "Ermeni vilayeti" oluşturulması tesadüf değildi.

"Ermeni vilayetinin" ömrünün çok uzun olmadığı doğrudur, bu da Çarlık Rusya'sının acelesi ve umursamazlığı olarak değerlendirilmelidir. Çünkü "Ermeni vilayeti" kalsaydı, çarlık daha sonra "Gürcü vilayeti", "Türk-Tatar vilayeti" ve benzeri etnik-milli vilayetler kurmak zorunda kalacaktı. Bu, o zamanki Çarlık "böl ve yönet" politikasıyla henüz tam olarak uyumlu değildi.

Çarlık Rusyası, imparatorluğun çıkarları doğrultusunda Hristiyan sayısını artırmak yerine Kuzey Azerbaycan dâhil Güney Kafkasya'da Müslümanların sayısını azaltarak Hristiyan vilayetleri oluşturma sürecini başlatmıştır. $\mathrm{Bu}$ amaçla Çarlık Rusyası, 1818'den itibaren sadece Ermenileri değil, Almanları ve daha sonra da Rus Malakanlarını toplu halde olmasa da Kuzey Azerbaycan topraklarına yerleştirme politikası başlatmıştır. Sonuç olarak, 1900 yılına gelindiğinde, Kuzey Azerbaycan topraklarında yaklaşık 40.000 Rus nüfusun ikamet ettiği 41 Rus köyü vardı (Azerbaycan Tarihi, 2007:291-293).

\section{6. ÇARLIK RUSYA'SININ IŞGALINE VE ERMENI - RUS BASKISINA KARŞI ILK ITTIRAZLAR}

Çarlık Rusyası, Kuzey Azerbaycan toprakları da dâhil olmak üzere, Güney Kafkasya'da Hristiyan Ermeniler, Almanlar ve Rus Malakanlar'ın yeniden yerleştirilmesi planın ile ilgili bir idari yönetim politikası izlemişler ve yeni oluşturulan farklı yönetim sisteminde komutanlara mutlak güç vermişlerdir. Başka bir deyişle, o dönemde bu farklı yönetimdeki komutanlar aynı zamanda yürütme, yargı ve askeri güce sahip askeri garnizonun da başıydı. Bu mutlak gücü kullanarak Kuzey Azerbaycan halkına oldukça acımasız davrandılar. Onlara baskı uyguladılar. Hiçbir hak ve geleneklerini yaşamalarına izin vermediler. Tüm bunlar kısa sürede Kuzey Azerbaycan'in tüm bölgelerinde (Lenkeran, Car-Balaken, Quba, Şeki, Zagatala vb.) ulusal kurtuluş ayaklanmalarına yol açmıştır. Ulusal kurtuluş ayaklanmalarının önde gelen gücü, liderleri ulusal ve dini bilinç açısından oldukça olgun olan kitlelerin kendisiydi.

1830 sonbaharında Car-Balaken'daki komutan ofisinin, komutan Korniyenko ve 1831'de Lenkeran'daki çevresi, 1837'de Quba'daki komutan Gimbut ve çevresi ve 1837'de yeniden Şeki'deki komutan ofisine karş1 keyfi bask1 ve ahlak dışı davranışlarına karşı ulusal kurtuluş hareketleri Rus hâkimiyetine asla katılmamanın örneklerini oluşturmaktadır (Azerbaycan Tarihi, 2007:106-117).

Azerbaycan'ın Karabağ bölgesinde doğan Baba Bey Şakir, "Qazim bey Zekire" şiirinde Karabağ-Şuşa'daki siyasi olaylardan, rusların işgalinden sonra Kuzey Azerbaycan'da beylerin, bilgelerin aşağılandığından ve rusermeni zulmünün arttığından bahsetmiştir (Azerbaycan Edebiyatı, 2009:14);

"Vilayatda urus olub ixtiyar,

Eylayib bir bina yoxdu göran kar,

Tamam işlar olub cahila bazar,

Heyif bu vilayat, heyhatü heyhat!."

Şakir, açıkça Azerbaycan'ın Karabağ bölgesindeki hanlığın milli ve dini değerlerine Rus işgalinin ağır bir darbe indirdiğini ve keyfiliğin en üst düzeye ulaştığını yazmıştır (Azerbaycan Edebiyat1, 2009:15). Şair, "Gancüm ağaya" adlı şiirinde, Rus kanunlarının Azerbaycan halkının milli ve dini gelenekleriyle uyumsuzluğundan ve yeni hesabın zararından bahsetmiş̧ir. Buna dayanamayanların ya Rus işgaline karşı savaştığını ya da anavatanlarını terk etmeye zorlandıklarını yazmıştır (Azerbaycan Edebiyatı, 2009:17).

Şakir'in bu şiirlerinden anlaşılmaktadır ki, Çarlık Rusya'sının işgali, Kuzey Azerbaycan halkının düşünce ve yaşam tarzlarında olumsuz etkilere neden olmuştur. Azerbaycan'ın kuzeyinde Çarlık Rusya'sının Sovyet 
döneminden beri işgalini meşrulaştırmaya çalışmanın mazereti olamaz. Çünkü bu işgal, Sovyet Rusya'nın ideologları ve araçları tarafından icat edildiği gibi "ilerici" değil, kelimenin tam anlamıla vahşice idi.

Kasım Bey Zekir, Çarlık Rusya'sının sömürge politikasından kaynaklanan adaletsizlikleri ve haksızlıkları eleştirmiştir. Örneğin, eleştirel şiirinde "Bölgenin Kargaşası Üzerine", Karabağ'da Çarlık Rusyası'nın işgalinden önce var olan kuralların izlerinin kalmadığını yazmıştır. Bunun yerine adaletsizlik çok fazlaydı ve "yalvarmaya" benzettikleri çarlık memurları ve onlara bağlı Ermeniler hakkında şikayette bulunanların konuşmasına izin verilmemiş ve susturulmuştur (Zakir, 2005:22). Zakir, Çarlık Rusya'sının Azerbaycan Türk topraklarına ayak basmasından sonra kötülüğün arttığını ve iyiliğin azaldığını anlatmış ve onun haklılğı daha sonra anlaşılmıştır.

Kısacası adalet sözde kalırken, gerçekte kötülük ve aldatma yer almıştır (Zakir, 2005:36). Burada Zakir, Çarlık Rusya'sının işgalinin bir sonucu olarak ulusal ve dini hakların ihlal edildiğini incelikle ifade etmeye çalışmıştır. Yani sömürgeleştirme sonucunda Türkler kendi topraklarında köle olmuş ve Ruslara bağlı olan Ermeniler ise efendi olmuşdurlar. Zakir bu durumu şu mısralarla ifade etmiştir (Zakir, 2005:44);

"Na gündə yaradıb xudavand bizi,

Bir yana apara bilmadik izi,

Gahi Avanesi, gahi Sərkizi,

Gahi do Semyoni göran canımız!

Bay ikən adımız oldu mülkadar,

Dəxi mundan bela bizimçün nə var?

Olmazını mükaddar, sahibi ixtiyar

Ovaki, Ortuni göran canımız!"

Ancak Zakir, divanların arkasında Kafkasya milletvekillerinin, Azerbaycan Türkleri'nin han ve beylerinden köylülere kadar her şeye haksızlık eden Çarlık Rusyası yetkililerinin olduğunu çok iyi biliyordu. Azerbaycan'ın Karabağ bölgesinde sömürge eylemleri sonucunda milli gelenek ve görenekler ortadan kaldırılmış ve yerini Rus "yasaları" almıştır. Zakir bu duurmu şu şeklide ifade etmiştir (Zakir, 2005:87):

"Yox bir deyən, ey varisi-macmui-Qarabăg,

Səndə ă̆alıq qaidəsi, adəti hani?

Pişək qoyan adını garəkdir ola pirşov,

Həm gözlüya bir-bir yorulub dalda qalanı"

Karabağ'ın Zangazur bölgesinden Seyid Mir Hamza Nigari, Karabağ-Azerbaycan'dan Türkiye'ye gidişinde Çarlık Rusyası ailesinin zulüm ve baskısında önemli rol oynamışırı. Bu anlamda Nigari, Çarlık Rusyası'nın saldırganlık politikasına da karşı çıkmış ve bazı şïirlerinde Moskova'nın sömürgeciliğini açıkça kınamıştır. Örneğin (Nigari, 2012:6);

"Mardi-mardana o qaplansifati-Moskof ilan

Eylamək cangü cadal şiri-Dağıstana düşər"

O dönemde "Ekinci" gazetesinin (1876-1878) sayfalarında, Hasan bey Zardabi'nin milli-dinsel birlik meselesine yeni yaklaşımının bir sonucu olarak, zamanının Ermeni liderleri alarma geçmiştir. 1870'lerde Tiflis'te yayınlanan Ermeni gazetesi "Mşak", sayfasında Zardabi'nin Ermenice yazısını yayınlayarak, zamanımız bir bilim dönemi olmasına rağmen Müslüman aydınların da birlik olduğunu iddia ettiklerini ve tüm İslam halklarını Mekke'ye gitmek adına "Birlik-İslam" İle birleşmek istediklerini ifade etmiştir.

Mşak, yazısında, "Geçmişte zorla işgal ettiğiniz topraklarımızı bize verin ve sonra İslam'ın inşa edildiği çöllerde İslam Birliği'ni sağlayın ve Moğol kabilesini birleştirin, çaba gösterin" (Zardabi, 2005:350), ifadesine yer veriyordu. Böylece Ermenileri için İslam Birliği'nden ziyade "Moğollar" olarak adlandıran Türklerin uyanış1 ve "İslam Birliği" olarak da bilinen milli kimlik içinde Türk-İslam birliğinin ortaya çıkması endişelendiriyordu. Zerdabi, bilim, eğitim ve diğer alanlarda o dönem Kafkas-Azerbaycanlı Müslümanlardan daha gelişmiş olan Ermenilerin amacının farkındaydı.

Zardabi, yukarıda yapılan açıklamalar bağlamında Ermenilerin endişesine ve tacizine cevaben, "Ey muhterem Aesruni yıllardır Ermenilerle komşuyuz ve şimdi aramızda düşmanlık yaratmanı efendiniz için utanç verici" 
(Zardabi, 2005:350), demiştir. Zardabi, büyük bir öngörü ile Kafkas-Azerbaycan Müslümanlarını yani Türkleri birlik olmaya davet etmişti. Zamanla Türklerin komşuları olan Ermeniler ve Gürcüler tarafından atılan adımların farkına varan Zerdabi, milleti arasında milli fikirleri yaymaya çalışmıştır (Zardabi, 2005:273).

\title{
7. GÜNEY KAFKASYA'DA 1905-1906'DA ERMENİ - MÜSLÜMAN ÇATIȘMASI
}

20. yüzyılın başlarında Japonya ile savaşta (1903-1904) yenilgiyle birlikte Dünya iktisadi buhranından (19011903) kurtulamayan ve özgürlük, işçi sınıfın mücadelesinin genişlemesi Çar Rusya'sını zor duruma düşürmüştür. 9 Ocak 1905 yılında II. Nikolay’ın binlerce insanın şikâyetlerini dinlemek yerine onları kurşuna dizmesi ülkedeki problemin çözümüne katkı sağlamamıştır.

Çarlık devrimci hareketini önlemek, halkın dikkatini başka yöne çekmek için etnik gruplar arası katliam yapmıştır. Böylece Çarlık Rusyası, Kuzey Azerbaycan'da devrimci-Marksist ve milli-demokratik hareketlerin büyümesinden endişelenerek Güney Kafkas bölgesinde ermeni-müslüman çatışmasına (1905-1906) göz yummuştur. Bu çatışamada Kuzey Azerbaycan Türkleri ve Kuzey Azerbaycan topraklarında yaşayan müslümanlar acı çekmiştir (Mammadov, 2005:327).

20. yüzyılın başlarında Azerbaycan ulusal basınında "Ermeni meselesini" yazan Azerbaycanlı Türk aydınları (Ali bey Hüseynzade, Muhammed Emin Resulzade, Ömer Faig Nemanzade, Yusuf Talıbzade, M.Said Ordubadi $v b$.) Ermeni meselesinin Batının ve Rusya'nın bir oyunu olduğunu beyan etmişlerdir. Milli aydınımız Ali Bey Hüseynzade, Batı'ın kasıtlı olarak Ermenileri Müslümanlara karşı kışkırttığını söylemiştir. Ermeniler de Batı ile Rusya arasındaki oyunun bir parçası olmuş ve Müslümanları öldürmüşlerdir. Bu anlamda yüzünü Ermeni yazarlara (Nikoksov ve diğerleri) çeviren Hüseynzadeh şu ifadelere yer vermiştir (Hüseynzade, 1905);

\begin{abstract}
"Birlikten ve ittifaktan mı korkuyorsunuz? ... Ve biz anlaşmazlık ve çekişmeden korkuyoruz! Aramızda çok fazla kan dökülmesine neden olan bir tartı̧̧ma ve kavga değil mi? Kafkasya'mızda sanki bu uyuşmazlık, bu düşmanlık ve nefret yenmemiş gibi, İttihadi-Müslim'in hatırası için genel dünya-İslam'da bir uyuşmazlık mı olmalı, yoksa başka bir Müslümanın kanını mı dökmeli? Bunu istiyor musunuz? .. Hayır, sizi korkutan bir birlik ya da ittifak değil! .. Bin üç yüz yıldır zaten var. Aranızdaki sebep cehalet, ihmal ve yanlış yönlendirme iken, Ermenilerin çoğunluğu kendini beğenmişken, İslam dünyasından değil, uyanıştan, yenilenmeden ve aydınlanmadan korkuyorsunuz!"
\end{abstract}

Güney Kafkasya'da Ermeniler ve Ruslar, Türk ve diğer Müslüman halklara karşı yaptıkları katliamın önlenmesinde ünlü bir Türk aydın, siyasetçi Ahmed Bey Ağaoğlu 1906 yazında "Difai” önemli bir faaliyet olmuştur. Baykara'ya göre "Difai" Türk nüfusunu Ermeni Taşnakların silahlı kuvvetlerin katliamlarından korumak amaciyla oluşturulmuştur (Baykara, 1992:70-80). Ünlü bilim adamı T. Svyatohovski konuyla ilgili olarak; "Tatar-Ermeni ihtilafinın (savaşının) bir sonucu olarak ortaya çıkan 'Difai' Şamil döneminden bu yana, esas olarak Rusya karşıtı faaliyetleri nedeniyle hiçbir zaman karşı karşıya gelmeyen çarlık rejimine, itaatkârlara bir darbe indirmiştir" (Svyatohovsky, 1990:101) ifadesini kullanmıştır.

Difai'nin lideri Ağaoğlu, 1902'de yazdığı bir yazısında Ermeni milliyetçiliğinin gerçek mahiyetini göstermeye çalışmıştır (Ağaoğlu, 2019:119). Ayrıca "Kafkasya'da Ulusal Sorun" (1904) adlı makalesinde milliyetçiliği "iyi" ve "kötü" olarak kategorize etmiştir. O'na göre, Kafkasya'da Ermeniler gibi kötü milliyetçilikle enfekte olmuş topluluklar vardır (Ağaoğlu, 2019:123). Ağaoğlu'na göre Ermenileri etkileyen "kötü milliyetçilik", öncelikle kapitalizmin Avrupa'da yayılmasından kaynaklanmıştır. Burjuvazi ve milliyetçilik iç içe girmiştir. Burjuvalı olup milliyetçi olmamak imkânsızdır. Bu bağlamda şu satırlara yer vermektedir (Ağaoğlu, 2019:122);

"Sermaye soygununda hiçbir şeyi önemsememek kozmopolitliktir. O, Kendini, başkalarını, Yahudileri de aynı kolaylıkla yok etmektedir. Ancak onun kozmopolitliği bunun ötesine geçememektedir. Birini yok etmek gerektiğinde ve diğeri bunu gönüllü olarak yapmak istemediğinde sermaye kendini en kötü anlamda bile milliyetçi olarak göstermektedir."

Ağaoğlu, "Bakü'deki Olaylar Üzerine" başlıklı makalesinde (St. Petersburg Vedomosti, 21-22 Nisan 1905), Kuzey Azerbaycan'ın Çarlık Rusya'sına ilhak edilmesinden sonra Ermeni nüfusunun artmasının ve Müslümanlara karşı yükselişinin tesadüfî olmadığını yazmıştır. Özellikle Kafkas Müslümanlarının kültürel ve ulusal uyanışı Ermenileri rahatsız etmiştir. Ağaoğlu (1995) bu bağlamda;

"Bundan bahsetmişken, Müslümanlar ve Ermeniler arasında herhangi bir dini veya milli düşmanlık olduğunu sanmıyorum. Aksine, onlar yüzyıllardır barış ve dostluk içinde yaşadılar ve şimdi bile, kültür benzerliklerinin korunduğu her yerde - ortak emekle bağlı oldukları köy ve mezralarda, 
düşmanlık ve ayrımcılık olmaksızın samimi komşular olarak yaşıyorlar. Ancak kültürel gelişme açısından daha ileri olan açgözlü burjuvazinin ve Ermenilerin Müslümanları elbette ele geçirmeye ve egemen olmaya çalıştıkları tüm kentlerde çatışma ve protestolar kaçınılmazdı",

bilgilerine yer ermiştir. Ağaoğlu, Çarlık Rusya'sının bu çatışmayla Ermeniler kadar ilgilendiğini ve hatta Azerbaycan'daki Türk-Müslüman nüfusun katledilmesine Türk Ermenileri de (Andronik vb.) bu olayların içinde olmuştur.

Azerbaycanlı Türk aydınlarından Nasib Bey Yusifbeyli de Ermenilerin "Birlik-İslam" konularını Hristiyan kardeşlerin yardımına güvendiklerinden dolayı gündeme getirdiklerini ifade eder. $\mathrm{Bu}$ açıdan Ermenilerin gazetelerde Müslümanlara karşı her türlü iftira ve yalan beyanlarda bulunmuşlardır. Yusifbeyli konuyla ilgili olarak, "İttihad-i Islam" hakkında yıllar içinde ne yazılmadı ne de söylenmedi? Ermeniler gece uyuyup, rüyalar görüp, kurgular hazırlayıp ve bu konuda düzenlemeler yaparak, gündüzleri dünyanın her tarafindaki gazeteleri dolduruyorlardl" (Gahramanl1, 2008:120), demiştir.

Yusifbeyliye göre, Ermeniler boş hayaller peşindedirler, onların iddia ettikleri manada Müslümanların tek bir devlette birleşmelerine hiç de ihtiyaç yoktur. Çünkü Müslümanlar, Hristiyanlara veya diğer gayrimüslimlere karşı bir devlette birleşmek yerine kendi içlerinde birleşmenin ve bütün olmanın yollarını aramaktadırlar. O’na göre, İslam birliği konularından rahatsız olan sadece Ermeniler değil, aynı zamanda Avrupa'nın önde gelen aydınları ve onların basını da çok rahatsızd. Avrupalılar, tüm Müslümanların tek bir devlet veya Osmanlı İmparatorluğu etrafında birleşmelerinin kendileri için tehdit oluşturacağını düşünmekteydiler. Bu nedenle, bazı Müslüman düşünürlerin İslam Birliği hakkındaki yazıları da bu konuyu daha da zorlaştırmaktaydı (Gahramanlı, 2008:121-122).

Azerbaycan Cumhuriyeti'nin kurucusu, ulusal ideologu Muhammed Emin Resulzade, tüm bunları Çarlık Rusyası tarafından ekilen ulusal nefretin bir tohumu olarak nitelendirmektedir. Ermeni ve Türk barışseverlerin birleşmesi halinde Çarlık Rusya'sının iki komşu halkı düşman yapamayacağından umutluydu. Bu açıdan konuşan Resulzade, 1905-1906 yıllarında Türk-Müslüman katliamında Ermeni milliyetçilerinden daha çok Rus hükümetini ve Rus şovenistlerini suçlamıştır. Bu hususta (Resulzade, 1992:21);

"Bilindiği kadarıyla Goloşşapov," barışçı "olarak Şuşa bölgesine gönderildi. Goloşşapov da "barışı koruma" görevini yerine getirerek toplar, tüfeklerle ve ateşlerle barışmaya başlamıştır... Ey vicdansız Goloşşapov! Yeter, içtiğin insan kanı, iki ulusun birbiriyle çatışmasına sebep olup, sonra ikisini de bedi-faneye verdiniz! Bu kadar insaflizlık, vahşet olmaz ki, siz yapıyorunuz !! Nüfusun yaramaz ve barışsever olmadı̆̆ını varsayalım. Ama masum fakir insanlar, herhangi bir suç işlemekten aciz zayıflar, sakat olanlar, oğulları ve kızları, ne olursa olsun hiçbir şeyden suçlu değillerdir. Bu fakir, başıboş uluslardan ne istiyorsunuz? Onlara alamayacağın ne verdin? İnanın bana, bir gün ulusal mahkemenin önünde duracak ve eylemleriniz hakkında sorgulanacaksınız! $O$ gün korkun, infazcılar, insan kanına susamışlar!",

ifadelerine yer vermiştir. Bu makalede Resulzade, Ermeni-Türk çatışmasını bir "Ermeni meselesi" olarak değil, bir devrimden korkan Çarlık hükümetinin iki halk arasında kasten yarattığı "şeytani bir mesele" olarak değerlendirmiştir (Rasulzade, 1992:22).

Resulzade'nin söylediklerinin kuşkusuz bugün büyük bir anlamı vardır. Çünkü bugün bile birçok kimse tarafindan "Ermeni Sorunu", "Amerikan-İngiliz Çifte Standardı" ve "Rus Satanizm"'minin gerçek doğası anlaşılmamaktadır. Bu da kafamızda bir sorun olduğundan kaynaklanmamaktadır. Aslında çoğumuzun bu sorunları "anlamamasına" neden olan biziz. Bunun başlıca nedenleri, doğru ve milli ruhla eğitim eksikliği, çevreden kaynaklanan sorunlar ve en önemlisi kitlesel nitelikte bir milli ideolojinin olmamasıdır.

Azerbaycan'ın her vatandaşı kendi arzuları, istekleri ve kişisel inisiyatifiyle tarihi gerçeklerin farkına varma konusuna bir söz verilmeli ki, "Ermeni sorunu", "Amerikan-İngiliz çifte standardı" ve "Rus satanizmi" orta ve yüksek öğretim kademelerinde, sosyal medya ve farklı iletişim kanallarıyla millete iletilmelidir. O dönemlerde yaşamış Mir Möhsün Nevvab, ermeni-müslüman mücadelesi ile ilgili olarak, "bu çatışmanın asıl nedeni olan Rusların Ermeniler ile birlikte Türk-Müslümanlara zulmetmişlerdir" ifade etmiştir. Bu bağlamda Nevvab şöyle demektedir (Nevvab, 2006:94);

"Mascidi yandirıb aramənü rus,

Har iki qövm oldular manus,

Rahməti-haqdan olub məyus, 


\section{Var ümidim ki, iş ola məkus"}

Nevvab'ın ifadeleri doğru bir durum tespitidir. Ruslar ile Ermeniler, Müslümanlar-Türklerden gerekli cevabı almışlardır. Her halükarda Nevvab, Rusların oyununa gelen ve Türk-Müslümanlara saldıran hem Ermenilerin hem de taraftarlarının sonuçta mağlup edildiğini yazmaktadır (Nevvab, 2006:94).

1. Dünya Savaşı'na (1914-1916) katılan Türkiye düşmanlarına (Çarlık Rusyası, vb.) karşı savaştığı bir dönemde, bölgenin doğusunda yaşayan Ermeni çetelerinin ağaları Anadolu'da ve Azerbaycan'da bir Ermeni devleti kurmaya çalışmışlardır. Türk hükümeti ise Ermenilerin bu ihanetine tepki olarak bölgeyi boşaltmalarını emretmiştir. Özellikle 1915 yılı Nisan ayında çok sayıda Ermeni Türkiye'nin Doğu Anadolu bölgesinden sürülmüştür. Böylece Nisan 1915'teki yeniden yerleştirme harekâtını bir sözde "Ermeni soykırımı" olarak gören Ermeni Taşnaklar, bu tarihten sonra Türk ve Azeri Türklerine yönelik inanılmaz cinayetlerini daha da çoğaltmaya başladılar.

Azerbaycan Cumhuriyeti'nin kurucusu, ilk cumhurbaşkan1, Türk düşünür Muhammed Emin Resulzade, o dönem yazılarında "Ermeni meselesini" ele alarak, Ermenilerin Balkanlar'daki Osmanlı savaşını Türklere karşı saldırı için kullanmaya çalıştıklarını yazdı. Yani Ermeniler Türkiye'deki kriz durumunu Doğu Anadolu'da bir Ermeni devleti kurmak için kullanmayı hayal etmişlerdir.

Resulzade, 1913 'te "İkbal" gazetesinde yazdı̆̆ 1 "Biraz Ermeni Meselesi" başlıklı makalesinde, Ermenilerin şu anda bile Türkiye için bir sorun haline geldiğini belirtmektedir. "Bu Ermeni meselesi nedir? Bu, her şeyden önce bölgesel bir konudur. Bu, Türkiye üzerine araştırmalarıyla tanınan Avrupalı yazarların kabul ettiği bir gerçektir" (Resulzade, 2001:193). Resulzade, Ermenilerin iddia ettiği gibi Türkiye-Ermenistan diye bir şeyin olmadığını ifade etmektedir. Ona göre böyle bir kavramdan ne mantıksal ne de politik olarak bahsetmek anlamsızdır. Ermenilerin ve diğer milletlerin yaşadığı yalnızca birkaç vilayet vardır (Resulzade, 2001:194).

Resülzade, Kasım 1914'te "İkbal" gazetesinde yayınlanan "Ermeni Meselesi Çevresinde" başlıklı makalesinde, Ermenilerin Doğu Anadolu'daki Türk-Müslüman nüfusa yönelik işledikleri zulümlere bir kez daha işaret etti ve arkasında Çarlık Rusya'sının olduğunu yazmıştır. Ona göre Ermenilerin Türkiye'den ne istediklerinin netleşmediği bir dönemde Çarlık Rusya'nın onları Türk-Müslüman nüfusa karşı şiddete sürüklemesi tesadüf değildir. Çarlık Rusya'sının amacı, bağımsızlık iddiasıyla Hristiyan Ermenilerini Osmanlı aleyhine çevirmek ve Müslüman-Türk nüfusunu bu bölgeden temizlemekti (Rasulzade, 2001:425-426).

Resulzade, Ağustos 1916'da "Açık Söz" gazetesinde yayınlanan "Türkiye'deki Ermeniler" başlıklı makalesinde, Avrupa ve Rusya "Ermeni Meselesini" gündeme getirmeden önce, Ermenilerin Osmanlı İmparatorluğu'nda en üst düzeyde yaşadıklarını, hatta Osmanlı'da bakanlarının bile olduğunu yazmıştır: Türkiye'nin içişlerine karışmalarına kadar Türkiye'de rahat yaşadılar ve her zaman İstanbul hükümeti ile alay ettiler. Eski zamanlardan beri Ermeniler hükümette görev yapmışlar ve padişahların güvenini ve iltifatlarını kazanmışlardır.

Ermeniler, Osmanlı devletinde vezir bile olmuşlardır (Resulzade, 1916). Resulzade'ye göre 1877'den beri Balkan uluslarını takip etmek ve dış etkilerle kurtulmak isteyen Türk Ermenileri, İstanbul hükümetinin güvenini kaybetmişlerdir. Özellikle, 1915 yılında Türkiye'nin Doğu Anadolu bölgesindeki Ermeni ayaklanmaları ve bunun sonucunda Türk-Müslüman nüfusun Ermeniler tarafindan katledilmesi, İstanbul hükümetini Ermenilerin bir Osmanlı topraklarından diğerine yerleştirilmesi de dâhil olmak üzere bazı kararlar almaya zorlamıştır (Resulzade, 1916).

Azerbaycanlı Türk aydınlarından Ömer Faig Nemanzade, 1915 yılında Doğu Cephesi'nde başarısız Osmanlı askeri operasyonu "Sarıkamış"'ın ardından Rus-Ermeni güçlerinin saldırısına uğrayan Kars, Ardahan ve Kağızman halkına acil yardımın önemini anlatmıştır. Ömer Faiq, Ocak 1915'te Bakü'de yayınlanan İkbal gazetesinde, "Savaş dolayısıyla Kafkas müslümanlarının karşılaştıkları felaket küçümsenemezdi”, demiştir.

Kars bölgesindeki felaketi Bakü ve Gence'ye gelen 40-50 ev ve Ahıska köylerine sığınan birkaç yüz Müslüman ile karşılaştırmayın. Felaket, hayal edebileceğinizden daha korkunç, hayal edebileceğinizin çok üstündedir. Afet ve sefalet Kars, Ardahan, Kağızman ve Olti ilçelerini tamamen ele geçirmiştir. Orada yüzbinlerce Müslüman yardıma muhtaç bir haldedir (Nemanzade, 2006:183).

Faiq, "Bir lokma ekmek", "Sınav" gibi yazılarında Anadolu Türkleri ile birlikte durmamız gerektiğini de yazmıştır. Dolayısıyla Birinci Dünya Savaşı, tüm dünya milletleri gibi Anadolu ve Azerbaycan Türkçülügünün de bir sınavla karşı karşıya olduğunu bir kez daha göstermiştir. Nemanzade, bu sınavın eksik olduğumuz birçok yönünün yanı sıra milli birliğimizin ve eşitliğimizin özelliklerini de gösterdiğini yazmıştır. Konuyla ilgili olarak Nemanzade (2006:192); 
"Bugünkü sınavla dersimizi anlayıp geleceğe hazırlanırsak, çektiğimiz dertler, hakaretler ve acılar milletin geleceğine feda olsun. Doğru, bugünkü durumumuza bakınca ister modern ve gerek ruhsal manada devlet yöneticilerinden umutsuzum. Ancak milletin, halkın geleceine inancım sonsuzdur. Ĕger yönetimin başına bilgili, dürüst ve vatansever insanlar geçerse çok az bir zamanda uyanacağına umudum var"

ifadelerine kullanmıştır. Azerbaycan Türk aydını Ahmed Cevad Osmanli'nin Balkanlar ve I.Dünya Savaşı'nda düşmanlarına karşı yürüttüğü savaşlara doğrudan katılmıştır. Cavad, 1912 yılında Balkan Savaşı ile bağlantılı olarak İstanbul'da kurulan "Kafkas Gönüllüler Bölüğü" ne katılmış, Birinci Dünya Savaşı'na, Doğu Cephesinde Rus-Ermeni güçlerine karşı savaşan bir asker ve milli figür olarak bulunmuştur. Ayrıca Cavad'ın savaşlarla ilgili onlarca şiir ve yazısı bulunmaktadır.

Cevad 1. Dünya Savaşı sırasında (1914-1918) H.Z. Tagiyev'in himayesinde, Hosrov Bey Sultanov önderliğinde faaliyet gösteren "Müslüman Hayır Cemiyeti" nin başkan yardımcısı ve sekreteri olarak, Türkiye'ye her türlü yardımın örgütlenmesinde doğrudan yer almıştır (Saleddin, 1992:56-57). Cevad; Batum, Kars, Ardahan, Erzurum, Acariya ve diğer bölgelerde 4 yıl ön saflarda yer almıştır. 1915-1916 yıllarında "Açık Söz" gazetesinde yayınlanan "Acar Mektupları" nda, Birinci Dünya Savaşı'nda Türkiye'nin Doğu Cephesindeki durumuna tüm yönleriyle değinmiştir (Saleddin, 1992:56-57).

Cavad 1915'te Sarıkamış'ta Enver Paşa'nın Doğu Cephesi'ne gerçekleştirdiği başarısız askeri harekâtın ardından Rus-Ermeni askeri birliklerinin Kars, Ardahan ve Erzurum halkına karşı işledikleri suçlardan sonra ihtiyaç sahiplerine yardım etmek için elinden geleni yapmıştır. Cevad, memleketlerinden sürgün edilen Kars ve Erzurum'daki yurttaşlarımıza, düşmanın izinden topraklarımıza ithaf ettiği "Savaşçılar" şiirinde şöyle yazmıştır (Cavad, 2005:56-57);

Baxdım o yerlardə buludlar ă̆lar,

Mozarlı̆̆a dönmüş̧ bağçalar, bağlar,

Maralsız qaldınız, a qarlı dă̆lar,

Tutan olsa Sizdən maral soră̆l.

Göracak ki, har yer düşman yată̆ı!

Mayıs 1917'de Bakü'de yayınlanan "Kardeş Yardımı" dergisi, Ermenilerin Doğu Anadolu'daki Türk-Müslüman nüfusa karşı gerçekleştirdiği trajedilere adanmış ayrı bir yayındır. Bu derginin basılmasındaki temel amaç, bir yandan Doğu Anadolu'daki Türk-Müslüman nüfusun başına gelen trajedileri dünyaya duyurmak, diğer yandan da Türk-Müslüman dünyasının yardımına katkı sağlamaktır. Dergide yayınlanan makalelerin yazarları O.F. Nemanzade "Ben Kimim", M.E. Resulzade "Bizim açımızdan Rusya'da cumhuriyete güven", Hosrov Bey Sultanov "Bakü Müslüman Hayır Cemiyeti Askeri Yardım Dairesi Faaliyetleri”, M. Y. Ceferov "Müslüman Askerlere ve Müslüman Avukatlara Yardım", Fateh Kerim "Millet Sağ Olsun", Hüseyn Mirza Camalov "Umut", Halil İbrahim "Savaş ve Kadınlar", Firudin Bey Köçerli "Hayvanlar ve İnsanlar", Seyid Hüseyin "Beyazlayan Dişler" ve diğer ulusal entelektüellerdi.

Hosrov (Hüsrev) Bey Sultanov, "Bakü Müslüman Hayır Cemiyeti Yardım Dairesi Faaliyetleri” başl1klı makalesinde, Ermeni-Rus askeri gruplarının Dernek aracılığıyla Doğu Anadolu'da işledikleri trajedilerden etkilenen nüfusa Azerbaycan Türklerinin yardımından söz ederken (Sultanov, 1917:49-50), Ceferov "Dava ve Müslüman Avukatlar" yazısında ise daha çok 4. Devlet Dumasında Türk-Müslüman avukatların yaptıkları çalışmalardan bahsetmiştir (Ceferov, 1917:43-44). Halil İbrahim ise, "Savaş ve Kadın" başlıklı makalesinde Doğu Anadolu'da Rus-Ermeni çeteler tarafından soykırıma uğrayan kadınlar konusuna değinmiştir. Ona göre, savaş sırasında kadınların çoğu omuzlarında bir yük taşıyordu. Halil İbrahim, Kafkas cephesinden en çok etkilenenlerin Çarlık Rusya'sının köleliği altında yaşayan Türk-Müslüman kadınlar olduğunu yazmıştır (İbrahim, 1917:66-67).

Firudin Bey Köçerli de savaşın meydana getirdiği vahşi duyguları "Hayvanlar ve İnsanlar" yazısında ifade etmeye çalışmıştır. F.B. Köçerli (1917:74-75);

"Bugün dünyayı kan gölüne çeviren ulusların çatışması ve labirentlerinde görülen anlaşmazlık ve zulüm, insanlığın ileriye değil geriye gittiğine işaret ediyor gibi görünüyor. Bu düşmanlık ve çelişki, bu kan dökülen vahşi insanlar arasında gerçekleşmiş olsaydl, dünya kendini bir şekilde cehalet olan suç ve günahtan arındırmak zorunda kalacaktı. Ancak ne yazık ki, bu yozlaşma ve düşmanlık en medeni ve parlak Avrupa ulusları arasında yaygındır. Bu mücadelede her millet 
maddi ve manevi ilerlemesini, mutluluğunu ve refahını başkalarının ölümü ve yıkımında görür ve tüm gücüyle bu yolda gayret gösterir",

demiştir. Aynı zamanda "Kardeş Yardımı" dergisi, Ermenilerin Doğu Anadolu'daki Türk-Müslüman nüfusa karşı işledikleri trajediler ve Türk kardeşlerimize yardım etme ihtiyacı hakkında şiirler de yayınlamıştır. Bu şiirlerin yazarları H. Cavid "Savaş ve Afet", A.Nazmi "Taht İleri", M.S. Ordubadi "Özgür Özgürlüğe", A.Sahhat "Tahliye veya Mülteci", Salman Türkhan "Tamamı Türkçe Oluşmuş Dizin” ve diğerleridir.

\section{ERMENILER VE AYSORLAR TARAFINDAN GÜNEY AZERBAYCAN'DA TÜRKLERE KARŞI ISSLENEN TRAJEDILER VE OSMANLI TÜRKLERINIIN YARDIMI}

Birinci Dünya Savaşı, Kafkas cephesinde olduğu gibi Güney Azerbaycan'da da Osmanlı-Rus savaşlarını kaçınılmaz hale getirmiştir. Böylece, Ruslar ve İngilizler öncelikle Hristiyan Ermenileri ve Süryanileri her alanda kazanmak için, dolaylı olarak da Türk-Müslüman nüfusunun soykırımında desteklemişlerdir. Böylece, Çarlık Rusya'sının I. Dünya Savaşı'na ilişkin tarafsızlığına rağmen, Ağustos 1907'de İngiltere ile "iktidar paylaşımı" anlaşması sonucunda Güney Azerbaycan'a hâkim olmaya başlayan Çarlık Rusya'sı, 1912'den itibaren burada askeri güçlerini daha da genişletti. Osmanlılara yönelik askeri müdahale Azerbaycan Türklerinin ciddi protestolarına neden olmuştur. Araştırmacılara göre Rus ordusuna katılan Osmanlı, Salmas, Urmiye Süryanileri ve Ermenilerin say1s1 100.000'dir (Malikzade, 2010:12).

Osmanlı birlikleri 1914'ün sonlarında ve 1915'in başlarında Tebriz, Salmasi ve Urmiye'yi ele geçirmelerine rağmen, Rus ordusu Erzurum'da Sarıkamış'ın yenilgisinden sonra bu şehirleri geri alıp Azerbaycan'daki konumunu güçlendirmiştir. Rus işgaliyle uzlaşmayan Tebriz halkı, 4 Nisan 1915'te protesto mitingi düzenleyerek Rusların Azerbaycan'ı terk etmesini talep etmiştir.

Böylesine karmaşık bir durumda Asuriler ve Ermeniler, Rusların ve İngilizlerin doğrudan yardımıyla askeri olarak örgütlenmiş ve Osmanlı ve Azerbaycan Türklerine, halka karşı savaşmaya teşvik edilmişlerdir. Mayıs 1915'te büyük bir Süryani grubu, Rusların kışkırtmasıyla Osmanlı devletine ve bu anlamda Azerbaycan Türklerine savaş ilan etmşlerdir. Çünkü Süryaniler, Gacar eyaleti topraklarında ve Urmiye, Salmas gibi Güney Azerbaycan'ın büyük şehirlerinde Türk-Müslüman nüfusa karşı büyük çaplı katliamlar veya soykırımlar gerçekleştirmişlerdi. Örneğin, 1915 yılında, yaklaşık altı (6) Urmiye valisi olan Moiz, Urmiye de dâhil olmak üzere Azerbaycan'da Asurîler ve Ermeniler tarafından işlenen suçlar hakkında Azerbaycan mali işler müdürü'ne yazılı bilgi göndermiştir (Melikzade, 2010:53).

Moiz, Tebriz'deki Gacar Veliaht Prensi'ne yazdığı bir mektupta, tüm uzlaşma çabalarına ve hatta önde gelen isimler ve Amerikalı ve Fransız misyonerlerle barış girişimlerine rağmen, Azerbaycan Türklerine ve Müslümanlarına yönelik Hristiyan saldırganlığının artmakta olduğuna işaret etmiştir (Melikzade, 2010:55).

Rusya ve İngiltere'nin yardımıyla Osmanlılara savaş açan Asuriler ve Ermeniler, özellikle Asur lideri Mareşimon, Türk-Müslüman nüfusa karşı katliamlar yaptıklarında Çarlık Rusya'sından büyük askeri destek almışlardır. Kısa süre sonra Avrupa ve Amerika Birleşik Devletleri'ndeki Hristiyan misyonerler tarafindan büyük ölçüde finanse edilen (Mlikzadee, 2010:78-79) ve genellikle Rusya, İngiltere ve ABD tarafindan silahlandırılan Süryaniler ve Ermeniler, Doğu Anadolu'da Osmanlılarla 1916-1917 savaşına daha yakından dahil olmuş, Güney Azerbaycan'da on binlerce Türk ve Müslümanın katledildiği soykırımlara doğrudan katılmışlardır (Akgündüz ve Öztürk, 2008:283-285). T. Melikzade bu durumu, “Aysorlar ve Ermeni kaçak çeteleri şehirlere ve köylere akın etmiş, ve Ruslara güvenerek bir çok olaya karışmışlardır. O zamana kadar sadece halkın mallarını yağmalyyorlardı, ancak daha sonra geri dönüp insanları katletmeye başladılar" (Melikzadee, 2010:87), şeklinde ifade etmektedir.

Ekim 1917'de Rusya'daki Bolşevik devriminden sonra, Urmiye ve Salmas'taki Asurîler ve Ermenilerin suç eylemleri daha da yoğunlaşmıştır. Çünkü Rus ordusunun bu bölgeden çekilmesiyle İngiltere, Fransa ve ABD, Osmanlılara karşı yine Asuriler ve Ermenilere dayalı bir Hristiyan ordusu oluşturma kararı almıştır (Safari, 2016:48-49). Urmiye'deki Rus konsolosu Nikitin de anılarında Asurların, Rus General Potavzev ve ardından General Gashfild önderliğinde bir Hristiyan Ermeni ordusu yarattığını yazmıştır. Nikiti'nin verdiği bilgilere göre Güney Azerbaycan'da oluşturulan Hristiyan ordusuna İrevan ve Nahçıvan'dan 6.000 Ermeni katılmıştır. Bu durumla ilgili Melikzade şöyle yazmaktadır (Melikzade, 2010:9);

"Böylece Asur ordusu veya Azeri Süryanileri, Ermeniler, Osmanl cilolarından (Asurîlerinden) oluşmuş Hristiyan ordusu Azerbaycan ve bölgenin siyasi ve askeri sahnesine girmiştir. Azerbaycan'ın batısl, Osmanlı sinırl, Urmiye'den Araz Nehri'ne kadar tamamen Rus, İngiliz ve 
Fransiz Hristiyan ordusu tarafindan işgal edilmiştir. Böylece Asurilerin Urmiye ve Salmasda insanları öldürmek için ellerine firsat geçmiştir. Elbette bu acıların birkaç ana amacı vardı: Birincisi, bölgeyi Azerbaycan Türklerinden temizlemek ve Haydat (Büyük Ermenistan) teorisine dayalı bir Hristiyan devleti yaratmak. İkincisi, kamuoyunu Avrupa'daki savaştan uzaklaştırmak ve Osmanlı devletine karşı çevirmektir"

Görüldüğü gibi, 1917-1918 yıllarında Güney Azerbaycan'da, özellikle Urmiye ve Salmas'ta meydana gelen Türk-Müslüman katliamından önce, Büyük Britanya, Fransa ve ABD'nin tarafindan asuriler ve ermenilerden oluşan sözde "Hristiyan Ordusu" ya da "Aysor-Ermeni Devleti" önceden planlanmış ve uygulamaya konulmuştur (Safari, 2016:48-49).

Her halükarda, "İtilaf" ve onlara ait Hristiyan misyoner örgütleri tarafından sözde bir Hristiyan devleti oluşturmaya çalışıyorlardı. Bu sözde "devlet" liderleri Marshimon, Petros İllu ve diğerlerinin de amacı bir yandan Osmanlı'yla savaşı sürdürmek, diğer taraftan ise Türk-müslüman nüfusun, özellikle Azerbaycan Türklerinin soykırımını gerçekleştirmekti (Melikzade, 2010:101-106). "İtilaf"'ın himayesinde oluşturulan "Hristiyan Ordusu", Şubat 1918'in sonlarında Urmiye'de büyük çaplı bir soykırıma başladı. Melikzade bu konuda, "22 Şubat 1918 Cuma akşamı, Urmiye halkının ü̧̈ günlük katliamı başladı. Petros'un komutasında Asgerhan mahallesinin Süryanileri, Müslümanların yaşadı̆̆̆ komşu dairelere saldırdı”, demiştir.

$\mathrm{Bu}$ kadar hızlı ve acımasız bir saldırı beklemeyen Müslümanlar, beklenmedik bir şekilde yakalandı (Malikzadeh, 2010:117-118). Ancak Urmiye'deki Türk-Müslüman nüfusunun 25 Şubat'ta teslim olmas1 ve Hristiyan ordusunun şartlarını kabul etmesiyle katliam azalmıştır. Ancak ondan önce Urmiye'de en az 10.000 Türk-Müslüman, Asurlu ve Ermenilerin Hristiyan ordusu tarafından soykırıma maruz bırakılmıştır (Melikzade, 2010:129). 18 Mart 1918'de Hristiyan ordusu Urmiye'de yeniden katliamlar yaparak 10.000'den fazla TürkMüslüman'ı öldürmüştür (Melikzadee, 2010:162). Bu katliamların ana lideri, suikastta Marşimon'un yerini alan Petros İllu'dur.

Hristiyan ordusu, Urmiye'den sonra Azerbaycan'ın Salmas kentinde en büyük katliamlardan birini gerçekleştirmiştir. Böylece 1918 Nisan'ının başlarında Hristiyan ordusu Salmas'ta faaliyete geçti ve Salmas'ın Türk-Müslüman nüfusu için bir katliam başlattı (Safari, 2016:133-134). Salmas nüfusunun bir kısmı trajediden kaçmak için şehirden kaçarken, birçoğu soğuk hava nedeniyle yolda ölmüştür (Melikzade, 2010:177).

24 Nisan 1918'de Aysorlar ve Ermeniler Salmas'ın merkezi Dilmagan'ı ele geçirdiler. Çocuklar, yaşlılar ve kadınlar da dâhil olmak üzere Türk-Müslüman nüfusunu öldürmeye başladılar. Tüm bunlardan sonra 4 Mayıs 1918'e kadar Hristiyan ordusu Salmas ve çevresinde toplanan 40.000 Müslümanı Haftvan köyüne ve Sar kalesine oradan da başka yerlere götürdü. Bunun sonucunda çoğu yollarda öldü (Melikzade, 2010:193).

Urmiye ve Salmas Türk-Müslüman nüfusunun Ermeniler ve Süryaniler tarafından katledilmesi ve nüfusun geniş çaplı tahliyesinden sonra Gacar devleti, Kuzey Azerbaycan'da yaşayan Güney Azerbaycan Türklerinin bir kısmını bu bölgeye yerleştirme kararı aldı. Buradaki temel amaç, Hristiyan ordusunun soykırımından sonra Urmiye ve Salmas'ta önemli ölçüde azalmış olan bölgedeki Müslüman nüfusun dengesini sağlamaktı (Azeri, 1379:193).

Hristiyan ordusundan Urmiye ve Salmas da dâhil olmak üzere, Osmanlı askerlerinin Güney Azerbaycan'ın kurtuluşunda önemli bir rol oynadığına dikkat edilmelidir. Osmanlı Ordusu'nun 4. Kolordunun kahramanlıkları sayesinde, Urmiye ve Salmas'ın yanı sıra diğer Azerbaycan köy ve kasabaları birleşik Ermeni-Aysori ordusundan kurtulmuştur. Her halükarda, Osmanlı devleti ve Osmanlı-Türk ordusu, Güney Azerbaycan'ın yanı sıra Kuzey Azerbaycan'ın Türk-Müslüman nüfusunu Ermeni-Aysori askeri birlikleri veya Hristiyan ordusu tarafından tamamen yok edilmekten kurtarmada olağanüstü bir rol oynamıştır.

\section{9. ÇARLIK RUSYA'SININ DÜŞÜŞÜNDEN SONRA MART TRAJEDISİ VE KAFKAS TÜRKLERINNE SALDIRI GİRIŞiMI}

Çarlık Rusya'sının fiilen düşüşünden (Şubat 1917) sonra, Güney Kafkasya'yı yönetmek üzere üç halkı (Gürcüler, Türkler ve Ermeniler) temsil eden Tiflis'de (Gürcistan) ortak bir devlet organı kurulmuştur. Böylece, Şubat 1917'de Çarlık Rusya'sındaki Şubat burjuva devriminden ve çarlığın çöküşünden sonra, 9 Mart'ta Petrograd'da kurulan Geçici Hükümetin kararıyla, Güney Kafkasya'daki iktidar yeni oluşturulan bir yapıya Özel Güney Kafkasya Komitesi'ne devredilmiştir.

25 Ekim 1917'de Rusya'daki Bolşevik darbesi ikili bir iktidara yol açmıştır. 25 Ekim 1917'de Bolşevikler Rusya'nın Petrograd kentinde iktidarı ele geçirdikten sonra Bakü'deki Bolşevik-Taşnak unsurları daha aktif hale 
gelmiştir. 2 Kasım 1917'de Bolşevikler, yandaşları ile Bakü Sovyeti'nin bir toplantısını yaptılar ve Bakü'de Sovyet hükümetinin kurulduğunu duyurdular. Bu hükümetin başkanı ermeni asıllı Stepan Şaumyan olmuştur. (Azerbaycan Tarihi, 2008a:289).

Müsavat Partisinden Sovyet iktidarını ilan eden örgütün yapısına 22 milletvekili dâhil edilmiştir. Menşeviklerin ve Eserlerin aksine musavatçılar, özellikle Resulzade, Bolşeviklerin yönetimine ciddi bir şekilde itiraz etmediler. Özellikle, Lenin'in tüm halkların kendi kaderlerini belirleme yeteneği hakkında söyledikleri olumlu karşılanmıştır. $\mathrm{Bu}$ nedenle Eser-Menşevik bloğunun Sovyetler Birliği'nden çekilme önerisini "Musavat" tartışarak kabul etmemiştir (Azerbaycan Tarihi, 2008a:290). Ancak 12-13 Aralık 1917'de Bolşevikler ve musavatçılar arasındaki iliş̧ilerin gerginleşmesi ile Bakü Sovyeti'ne yeni seçimler yapılmıştır. Bolşeviklerin iradesi altında yapılan seçimler sonucunda yeni bir yönetici Komitede 6 Bolşevik, 5 Taşnak, 4 solcu Eser, 3 sağcı Eser ve 2 musavatçı yer almıştır. 18 Aralık'ta Lenin, Şaumuyan'ı Kafkaslar için özel bir komisyon üyesi (komissar) olarak atadı. Bolşeviklerin ikili oyun oynadıklarını, özellikle Türküstan'da Türk-Müslüman nüfusa karşı katliamlarını protesto eden "Müsavat" liderliği Bakü Sovyeti milletvekillerini geri çağırdılar.

Böyle zor bir zamanda, 11 Kasım 1917'de, RSFSR HKS'ye boyun eğmek istemeyen bir Gürcü Menşevikler, Türk musavatçılar, Ermeni Taşnaklar ve sağ Eserlerin temsilcileri Tiflis'te (Gürcistan) yaptıkları toplantıda Rusya'daki Bolşevik hükümetinin yönetimini tanımak istemediler ve "Bağımsız Transkafkasya Hükümeti" kurulması çağrısı yapılmasına karar verdiler. Böylece, Hüsusi Güney Kafkasya Komitesi yerine Güney Kafkası yönetmek için 15 Kasım'da Tiflis'te Y.P. Gegeçkorin'in başkanlığında Transkafkasya Komiserliği oluşturuldu. 5 Aralık 1917 yılında Transkafkasya Komissarlığı ile Türkiye arasında imzalanmış Erzincan antlaşmasına göre Rus askeri birlikleri Kafkas cephelerinden geri çekilmeye başladılar.

Şubat 1918'in başlarında, Tiflis'te, Güney Kafkasya'daki tüm Rusya şirketleri meclisine seçilen milletvekilleri toplantısında Transkafkasya'nın Yüksek Yönetim Organı olan Transkafkasya Seymi (parlamento) açıldı ve bölgenin ana güç merkezi oldu. 23 Şubat'ta çalışmalarına başlayan Seym'de ağırlıklı olarak üç parti - Musavat (Azerbaycan Türkleri), Taşnaktsutyun (Ermeniler) ve Sosyal Demokratlar (Gürcüler) Temsilcileri bulunmaktaydı. Seymdeki 44 milletvekilinden oluşan Azerbaycan ulusal fraksiyasının lideri ise M. E. Resulzade idi. Bu dönemde Osmanlı Devleti Gürcüler ve Ermenilerin Seym'de izledikleri politikayı kabul etmeyerek onlara karşı savaş ilan etti. Savaş sekiz günden fazla sürmedi ve Osmanlıların zaferiyle sona erdi. Türk fraksiyasının ısrarı ile 22 Nisan'da TransKafkasya Seymi ülkenin bağımsızlığını ilan etmiştir.

Türkiye ile anlaşmaları için Batum'a barış misyonu görevlilerini gönderilmeden önce Transkafkasya Seyminin (parlamentosunun) Türk-müslüman fraksiyasında konuşması sırasında Seymdeki Halk Eğitim Bakanı görevinde olan N.Y.Yusifbeyli en önemli konunun Azerbaycan Türklerinin zor günler yaşamasına, varlıklarının tehlike altında olmasına vurgu yapmıştır. O, konuşmasında net bir şekilde vurgulamıştır ki, Seym'de bulunan gürcüler, ermeniler Kuzey Azerbaycan'daki ermeni taşnaklarıyla rus bolşeviklerin türk-müslüman nüfusa karşı soykırım faaliyetlerine karşı duyarsız davranmaktadırlar (Vakilov, 1998:22-23).

Mart 1918 olayları sırasında Bakü'nün ve çevredeki bölgelerin Devrimci Savunma Komitesine başkanlık eden Şaumyan, Aralık 1917'de Lenin tarafından imzalanan "Türkiye topraklarında Ermenistan'a Özerklik Verilmesi" kararnamesinin çıkmasını sağlamıştır (Nasirov, 1993:22). Şaumyan'ın devam eden Azerbaycan ve Türkiye karşıtı politikaları, Lenin'in 1918'de ona gönderdiği bir telgrafta, "Sizin kararlı ve keskin siyasetiniz bizi mutlu etmektedir" (Quliyev, 1957:26), şeklinde ifade edilmiştir. 15 Mart 1918'de Bakü Sovyeti'nin bir toplantısında Şaumyan açıkça Bakü'nün Sovyetler Birliği'nin Güney Kafkasya'daki iç savaşın ana kalesine dönüştürülmesini beyan etmiştir.

Soykırım arifesinde, Taşnaktsutyun Partisi ve Ermeni Ulusal Konseyi, Bakü Sovyetinin tarafına geçmiştir. 3031 Mart'ta sadece Bakü'de 12.000'den fazla Türk-Müslüman nüfusu Rus-Ermeni askeri birlikleri tarafindan soykırıma uğramışlardır. Ayrıca Rus-Ermeni askeri birlikleri tarafından Kuzey Azerbaycan'ın Şamahı, Quba, Lenkeran, Kurdamir, Salyan ve diğer bölgelerinde on binlerce Türk-Müslümanı nufusu öldürülmüştür. Menşeviklere karşı uzun süredir savaşan Bolşeviklerin, menşevik ve Eserlerle, hatta kadet ve taşnaklarla Mart ayında birleşmesi dini ve milli temelde gerçekleşmiştir (Azerbaycan Tarihi, 2008a:301).

Sovyet tarihçilerinin ve bilim adamlarının Mart soykırımını ciddi şekilde incelemiş olmaları ve bu olayları vatan savaşı gibi göstermeye çalışmaları, buütün bu olaylardan Musavat Partisinin sorumlu olduğunu belirmeleri çok ilginç olmuştur. Ancak tartışmasız gerçekler Mart olayları sırasında Rus Bolşevikleri ve Ermeni Taşnakları ile birlikte Kuzey Azerbaycan Türklerine karşı soykırım yaptıklarını ortaya koymaktadır.

Azerbaycan Türklerine ve tüm Azerbaycanlılara karşı yapılan soykırımın yaşayan bir tanığ olan Muhammed Emin Resulzade 30-31 Mart olayları hakkında daha sonra şunları yazmıştır (Resulzade, 990:33); 
“Şaumyan'daki bu kartın etkisi öyle olmalıdır ki, bir ay önceki Bakü Belediyesindeki rus meclisini dağıtan bolşeviklere karşı bombalar atan "Taşnaksütün” örgütü "Bakü Sovyeti” ile slkı bir iletişime ve askeri alanda ittifak kurmuş oldu. Şaumyanın yönetimi altında bulunan "Bakü İşçi Ve Askeri Soveti” ermeni alaylarl ve "Taşnaksütun” tarikata menfaat sağlayarak Müslüman örgüte karşı şiddet içeren bir eylemde bulundu. Ermeni alayını gözlerinin önünde gören Müslüman halk, Tiflis'ten Müslüman alayın örgütlemek üzere gönderilen subayın "Sovyet" subayı olarak tutuklandığını görünce şok oldu. Her geçen gün artan yangın, nihayet bir nifak klvılcımına neden oldu ve 28-31 Mart 1918 tarihlerinde kanlı Mart olaylarına yol açtı"

Ermeni Taşnaklar ve Rus Bolşeviklerinin sadece Bakü'de en az 10.000 (on bin) Müslümanı öldürdügünü yazıyor: "Bu olay ile Bolşevikler, Bakü'deki birçok vilayette olduğu gibi kanlı operasyonlarını gerçekleştirdiler. Bakü Sovyeti işçi ve sivil iktidar adına, Ermeni alaylarıyla birlikte "Musavat" partisi ile "Milli Müslüman Konseyi”'ne savaş ilan etmiş ve 10.000 (on bin) fakir Müslümanı öldürmüştür.

Öldürülenlerin binlercesi silah taşımalarına izin verilmeyen yaşlılar, kadınlar ve çocuklardı (Resulzade, 1990:33). Resulzade, Ermenilerin ve Rus Bolşeviklerinin Müslümanlara yönelik vahşetinin nedenini şöyle anlatmıştır (Resulzade, 1990:33);

"Bakü, Türk milliyetçiliğinin merkeziydi. Rus partisinin Bolşevik hizbi bu merkezi yok etmek istedi. Bu bakımdan Rusya'nın geleneksel müttefiki olan Ermenilerin Türklere karşı olduklarını biliyorlardı. Aslında Mart olayları sırasında meydana gelen cinayet, hiç de bir sinı mücadelesine benzemiyordu. Tarafsı bir gözlemcinin gözünde bu, silah ve korumadan mahrum kalan Müslüman halkn acımasızca taciz edilmesinden başka bir şey değildir. Limandaki toplar, Ermeni askerlerinin yoğun ateşleri, uçaklar ve deniz topları Müslüman toplumunu hedef alıyordu. Müslüman mahallenin başına ateş yağıyordu ve cehennem püskürtülüyordu"

30-31 Mart 1918 Türk-Müslüman soykırımından sonra Bolşevik-Taşnakların Bakü Sovyeti'nin yönettiği 1 Nisan'da düzenlenen Barış Konferansı"nın ardından Bakü yönetimi tamamen onların idaresine geçti (Azerbaycan Tarihi, 2008a:303). Bakü Sovyeti Ermeni (Taşnak) ve Rus (Bolşevik) siyasi medya ve kuruluşları hariç, tüm gazete ve dergilerin, ulusal meclislerin faaliyetlerini engellemiştir. 25 Nisan'da S. Şaumyan'ın başkanlığında Bakü Halk Komiserleri Konseyi (BHKK) kuruldu ve onun yönetiminde çoğunlukla Ermeni taşnaklar ve Rus Bolşevikleri bulunmaktaydı. Bu anlamda Taşnak Ermenistanı'nın liderlerinden Hatisov, BHKK'ni "Ermeni Sovyet hükümeti" olarak adlandırmıştır. Dahası, BHKK kendisini Sovyet Rusya'nın ayrılmaz bir parçası olarak görüyor ve Azerbaycan'a bağımsızlık fikrini veya özerklik verilmesini kabul etmiyordu. Bunun gibi kabul edilemez olayla TransKafkasya Federal Demokratik Cumhuriyeti'nin çöküşüne neden oldu. Gürcistan'in 26 Mayıs 1918'de Transkafkasya Cumhuriyeti'nden ayrilmasiyla birlikte Seym (parlamento dağıldı) çöktü ve Kafkas birliği fikri yarım kaldı.

\section{AZERBAYCAN CUMHURIYETİ DÖNEMINDE KAFKAS BİRLİĞİ KONUSU VE KARABAĞ SORUNU}

Azerbaycan Cumhuriyeti döneminde Ermenilerin çifte oyununa rağmen Azerbaycanlı Türk aydınları Kafkasya Federasyonu faktörünü gündemde tuttu. $O$ dönemde Azerbaycan Cumhuriyeti'nin kurucusu Kafkas Konfederasyonu fikrinin yazarlarından biri olan ilk cumhurbaşkanı Muhammed Emin Resulzade bu konuda, "Azerbaycan'ı Kafkas Birliği'nin bir konfederasyon parçası olarak hayal ediyorum. Bu birlik devleti Azerbaycan, Gürcistan, Ermenistan ve Kuzey Kafkasya'yı kapsamalıdır" (Balayev, 2011:186), demiştir. Kasım 1919'da 2. Müsavat Kongresi'nde bu düşünceyi savunan Resulzade'nin girişimiyle toplantıya katılanlar Kafkasya Cumhuriyetlerinin Kafkasya Konfederasyonu'nun özgür birliği içinde birleşmesi için bir kararname imzaladilar (Balayev, 2011:186).

Resulzade'nin yanı sıra, ünlü Azerbaycan-Türk düşünürler Ali bey Hüseynzade, Ahmed bey Ağaoğlu ve Ali Mardan Topçubaşov da Kafkas birliği fikrini desteklemişlerdir. Topçubaşov, 1918 tarihli "Azerbaycan Cumhuriyeti'nin Kuruluşu” adlı kitabında, Güney Kafkasya'nın üç ulusunun (Türkler, Gürcüler ve Ermeniler) İsviçre Cumhuriyeti'nde olduğu gibi konfederasyona dayalı ortak bir siyasi hayata sahip olduğunu yazmıştır. Güney Kafkasya'da Konfederasyon yapısı şeklindeki düşünce çok yaygın olmuştur.

Bu fikir, 9 Nisan'da 1918'de tüm Güney Kafkasya'nın bağımsızlık ilanı ve ülkede hükümetin "Ağalık" egemenliği sözden icraata geçmiştir. Bu görüş hala yaşamakta ve taraftarları arasında Ermeniler, Gürcüler ve Azerbaycanlıların liberal ve milliyetçi partileri ile Güney Kafkasya'nın tüm ülkelerinin birleşmek isteyen sosyal demokrat partileri vardır (Topçubaşı, 2013:54-55). 
Turancılığın o dönem ideoloğu Ali Bey Hüseynzadeh bile böyle bir Kafkas Federasyonu kurulmasının mümkün olduğunu düşünüyordu. T.Svyatoçovski'nin aktardıklarına göre, o zamanlar A.Huseynzade Güney Kafkasya bölgesi için üç seçenekten yani "Kafkasya Federasyonu'ndan", "bağımsız Türk, Gürcü ve Ermeni devletlerinden" ve "Kafkas Türklerinin Türkiye ile birleşmesinden" bahsetmiştir (Svyatoçovski, 1990:103).

Fatali han, cumhuriyet döneminde başbakan olarak yeni kurulan devletin temel sorunlarını parlamentoda tartışırken diyordu ki, bir ulus-devlet oluşana kadar bir köyden diğerine gitmek korkutucu idi, hiç kimsenin hayatı, şerefin, canı veya malı güvende değildir. Ayrıca, Ulusal Konsey bir yandan Kuzey Azerbaycan'ın doğusunda S. Şaumyan başkanlık ettiği Bolşevik-Taşnaklarla, diğer taraftan ise Azerbaycan'ın batı kesiminde İrevan, Nahçıvan, Göyçe, Daralayaz'da işgalde bulunan Ermeni Andranik'in terörist gruplarına karşı mücadele etmek zorundaydı. Bu bağlamda, Hoylu, umudun tek yerinin Türkiye olduğunu kabul etmiştir. Bu hususta (Hoyski, 1998:112);

\begin{abstract}
"Azerbaycan olay anında bağımsız ilan edilmesine rağmen herhangi bir hükümet tarafindan tanınmamıştır. O dönemde Azerbaycan'ın tamamı tarafindan seçilen Milli Konsey bu hükümeti atadı ve idareyi devraldı. Beni başkan seçerek göreve başladım. Türkiye ile kısa sürede bir barış anlaşması imzalandı. Aynı zamanda, hükümet kanun ve düzen bakımından zayıftı. Çünkü harekete geçecek gücümüz ve silahımı yoktu. Açı bir hükümet kurmak zorunda kaldık ama bunu yapamadık. Bu nedenle bir güce ihtiyacımız vardı ve barış görüşmeleri sirasında Türklerden asker almak istedik. Bu teklifle başkasina başvurmak mümkün olmazdl. İsteseydik faydası olurdu. Türkiye hem dinimiz hem de milletimizdi"
\end{abstract}

Bu bakımdan birçok konuda, özellikle İrevan ermenilerine taviz konusuna göre Milli Konsey ve Ulusal Hükümeti eleştirenlere yanıt olarak Hoylu parlamento kürsüsünden, "Bu konuda çok şey söylenebilir. Fakat saate bakmak ve onu ölçeklere oturtmak gerekiyor. Bu faaliyetleri hangi hükumet? Ne zaman? Askerleri ve hazinesi olan bir hükümet mi? Ya da parasız ve askersiz iki günlük bir hükümet mi yapabilir?" (Hoyski, 1998:113), demiştir. Bu bağlamda dikkat edilmelidir ki, Ulusal Konsey İrevan topraklarını (9.000 metrekare) ermenilerin Nahçıvan, Karabağ ve diğer topraklardaki iddialarından vazgeçmesi ve savaşı durdurması sonucunda taviz verilmiş̧ir.

Nisan 1920'de, Sovyet Rusya Cumhuriyeti'ni devirmek için diplomatik baskılarla birlikte, yerel Bolşeviklerle ve Ermeni Taşnaklardan ve Türkiye'ye yardım bahanesini kullandı. Azerbaycan Komünist (Bolşevik) Partisi'ni kesin olarak elinde tutan Sovyet Rusya, Karabağ'daki yerel Türkleri Ermeniler vasitasıyla katledecektir. 22 Mart'ta Moskova'nın izni ile Ermeni çeteleri Hankendi'de konuşlandırılmış garnizona, Kazak ve Gence mahallelerine saldırdıya geçtiler. Azerbaycan hükümeti, milli orduyu Karabağ'daki Ermeni ayaklanmasını durdurmak için derhal Dağıstan sınırı ve Bakü'den tahliye etmek zorunda kalmıştır. Ancak cumhuriyetin kuzey sınırı korumasız kalmış ve kısa süre sonra Sovyet Rusya 11.Ordusu Azerbaycan'ı işgal etmeye başlamıştır.

\title{
11. SOVYETLER BİRLİĞİ'NDE (SSCB) KARABAĞ SORUNU VE "TRANSKAFKASYA FEDERASYONU" PLANI
}

Kuzey Azerbaycan'daki 11. Sovyet Rusya Ordusu'nun 27 Nisan işgalinden en çok Ermenistan faydalanmıştır. Böylece 29 Kasım 1920'de Ermenistan'ın Sovyetleşmesinden sonra Ermenilerin Nahçıvan, Zanegazur ve Karabağ'a yönelik toprak iddiaları daha da güçlenmiştir. Öncelikle 2 Aralık 1920'de RSFSR ile Sovyet Ermenistan arasında anlaşma imzalanmıştır. Antlaşmanın "üȩüncü maddesi" Rusya'daki Sovyet hükümetinin Ermenistanın 23 Ekim 1920'ye kadar elde ettiği toprakların İrevan Guberniyasının, Kars ilinin bazı ksımı, Zanegazur kazası, Kazak kazasının belli bir kısmı, Tiflis guberniyasının bazı kısmının "Sovyet-Ermeni Cumhuriyeti"ne dâhil olduğunu tartışmasız teyit etmektedir (Azerbaycan Tarihi, 2008:59). İlginçtir ki, Azerbaycan Komünist (Bolşevik) Partisi Merkez Komitesinin ve teşkilat ofislerinin 30 Kasım 1920'de gerçekleştirdikleri toplantılarda yaklaşık olarak aynı karar alınmıştır.

Kararda ayrıca Zangazur meselesine ve Karabağ'ın dağlık kesimine de değinilmiştir. Narimanov'a bu beyannameyi ilan etmek talimatı verilmiştir. Azerbaycan Tarihi'nin 6. cildinde bu hususta (Azerbaycan Tarihi, 2008:176);

"Kararda, N.N.Nerimanov konuşmasinda 1 Aralık 1920'de Bakü Sovyeti'nin bir toplantısinda açılklama yaptığı beyannamede Nahçivan konusu da gündeme gelmiştir. Ancak ertesi gün gazetelerde yayınlanan açılkamaya şu ifade eklenmiştir; 'Zengezur ve Nahçıvan toprakları Sovyet Ermenistani'nın ayrilmaz bir parçasıdır"”, 
ELEKBERLİ, Faiq - Yukarı Karabağ Probleminin Tarihi, Felsefi, Siyasi ve İdeolojik Açıdan Değerlendirilmesi

ifadelerine yer verilmektedir. Narimanov'un imzası ile yayınlanmış beyannameden sonra Ermeniler, Zangazur'un Ermenilerle birleşmesini hızlandırdılar. Zangazur'da Ermenistan'a bağlı Mehri bölgesinin oluşturulmasıyla Nahçıvan, Azerbaycan'dan ayrılmış oldu.

Azerbaycan'dan ayrılan Nahçıvan'ın kaderinde Türkiye belirleyici rol oynamıştır. Nahçivan'a "Türk Kapısı" adını veren Atatürk, Türkiye'nin anlaşmalarda Azerbaycan'ı savunması Nahçivan sorununun kaderini belirlemiştir. Türkiye'nin, askerlerini Nahçıvan'dan çekmeyi kabul etmesindeki asli etken Rusya'nın Nahçivanı Azerbaycan'ın ayrılmaz bir parçası olarak kabul etmesidir. Buna göre 16 Mart 1921'de Rusya ile Türkiye arasında Moskova'da bir dostluk antlaşması imzalanmıştır.

Antlaşmanın 3. maddesine göre Nahçıvan, Azerbaycan'ın bir parçası olarak kaldı ve üçüncü bir devlete taviz vermeme kararı alındı. Moskova Antlaşması'nın şartlarını daha ayrıntılı olarak belirlemek için, Eylül-Ekim 1921 döneminde Türkiye'nin Kars kentinde bir konferans düzenlemiştir. 13 Ekim 1921 Kars Nahçıvan Anlaşması'nın 5. maddesi ve üçüncü ekine göre burada Nahçivan'ın sınırları ve gelecekteki durumu açıkça tanımlanmıştır. Sözleşmenin en önemli yönlerinden biri ise bu anlaşmanın süresiz imzalanmasıydı.

31 Aralık 1923'te Azerbaycan Sovyet Sosyalist Cumhuriyeti Merkez Yürütme Komitesi, Azerbaycan SSC'nin bir parçası olarak Nahçıvan (MSSR) Özerk Cumhuriyeti kararnamesini kabul etmiştir. 8 Ocak 1924'te Trans Kafkasya Merkez Yürütme Komitesi, Azerbaycan SSC'nin bir parçası olarak Nahçıvan Özerk Cumhuriyeti'ni Otonom Sovyet Sosyalist Cumhuriyeti ilan etmiştir (Azerbaycan Tarihi, 2008:181). Aynı zamanda Ermenistan, Dağlık Karabağ üzerindeki iddialarından da vazgeçmemiştir. 19 Haziran 1921'de Ermenistan SSC (Sovyet Sosyalit Cumhuriyeti) Halk Komiserleri Konseyi Başkanı A. Myansikov'un beyanı ile "Dağlık Karabağ" Ermenistanın ayrılmaz bir parçası ilan edilmiştir.

SSC'nin Dağlık Karabağ'daki Tam Yetkili Olağanüstü Temsilcisi olarak atanan Mravyan N.Nerimanovun itirazları sayesinde 27 Haziran'da Ermenistan geri çağrılmıştır (Azerbaycan Tarihi, 2008:189). 27 Haziran 1921'de Azerbaycan Komünist (Bolşevik) Partisi Merkez Komitesi, siyasi ve örgütsel bürolarının ortak bir toplantısında Ermenistan'ın Karabağ'ın üst kısmındaki iddialarını reddetmiştir. Ancak Rusya Komünist (Bolşevik) Partisi'nin Kafkas Bürosu 4 Temmuz 1921'de Dağlık Karabağ'ın Ermenistan SSCB'ye katılmasına iliş̧in karar almıştır. Genel kurula katılan N.Narimanov bu haksız karara şiddetle itiraz etmiştir. 5 Temmuz 1921'de Rusya Komünist (Bolşevik) Partisinin Kafkas Bürosu, Dağl1k Karabağ'1 Azerbaycan SSR'nin sınırlarında şehrin idari merkezi olan Şuşa şehri olarak geniş bir bölgesel özerklik statüsü verilmiştir. Bu karar 27 Haziran 1923'te Rusya Komünist (Bolşevik) Partisi Güney Kafkasya Devlet Komitesi genel kurulunda onaylanmıştır. Azerbaycan MIK 7 Temmuz (belki 5) 1923 tarihli kararıyla Azerbaycan SSCB'nin sınırları içerisinde Dağlık Karabağ Özerk Bölgesi (DKÖB) oluşturulduğu ilan edilmiştir. Tüm bunların yanı sıra, Trans Kafkasya Federasyonu'nun Sovyetler Birliği veya Sovyet Sosyalist Cumhuriyetler Birliği (SSCB) döneminde kurulmuş olması çok ilginç olmuştur. Ancak bu defa Birlik Sovyet Rusya'nın baskısı ile zorunlu olarak oluşturulmuştur. Yine de 3 Kasım 1921'de Rusya Komünist (Bolşevik) Partisi Merkez Komitesi Kafkasya Bürosu ve 29 Kasım'da Rusya Komünist (Bolşevik) Partisi Merkez Komitesi Siyasi Bürosu Transkafkasya Federasyonu'nu kurmaya karar verdi.

18-22 Şubat 1922'de Tiflis'te (Gürcistan) düzenlenen Birinci Transkafkasya Komünistleri Kongresi'nde, Transkafkasya komünist örgütlerinin tek bir parti önderliğinde birleştirilmesi, "Kafkasya'nın yönetimini Merkezin elinde merkezileştirmeyi" hedefliyordu (Azerbaycan Tarihi, 2008:161). 10 Aralık 1921'de Transkafkasya Sovyetlerinin 1. Kongresinde en yüksek organ olan Transkafkasya Merkez Yürütme Komitesi seçilerek, Transkafkasya Sovyet Cumhuriyetleri Federal Cumhuriyeti (ZSRFR) kuruldu. 30 Aralık 1922 y1lında Moskova'da SSCB'nin 1. Sovyetler kurultayı gerçekleştirilmiştir. Burada da 4 cumhuriyet (Ukrayna, Beyaz Rusya ve ZSFSR esasında) SSCB temelinde kurulduğunu duyurdu.

Azerbaycanlı "sollar" Sovyet Azerbaycan'ın önce Transkafkasya Federasyonu temelinde birleşmesini, ardından Rusya'nın ilhakını savundu ve önderlikte temsil edilenlerin uluslararası bileşimi ile anlaştı. Çünkü "sol" akıma göre milliyet, millet, milli kültür ve milli bağımsızlık geçmişin kavramlarıdır ve yıkıma mahkûmdur (Mammadzade, 2007:65). Transkafkasya Federasyonu'nun kurulması mücadelesinde hareket eden Samad Agamalioğlu, Marksizm-Leninizm "halkların dostluğu" fikrinden söz ederek, ZSFSR birleşmesine karşı milliyetçiliğin ortadan kaldırılması gerektiğini yazmıştır. Bu perspektifte milliyetçiler - "sağcılar" - Azerbaycan Türkleri ile Ermeniler ve Gürcüler arasında ulusal bir fark olmadığını anlamalıydı. Bu bağlamda, "Ben bir Ermeni köyünde yaşarken, herhangi bir ulusal farklllık hissetmedim. Çünkü hikâyelerimiz ve şarkılarımız uyuyordu. Gürcüler arasında uzun süre yaşadım ve onların gelenek ve görenekleri de bizimkine çok yakındı" (Najafov, 1966:23), gibi söylemler geliştirilmiştir. Hatta bu söylemlerin yanında Ruhulla Akhundov'un "Sovyet Azerbaycan'ın, Sovyet Rusya dışında bağımsızlı̆̆ına gerek yoktur" gibi düşünceleri de ortaya konulmuştur. 
Rusya'nın doğrudan kışkırtmasıyla üç Güney Kafkasya devletinin birleşmesini ulusal barışın güçlenmesi olarak gören Akhundov, Müsavat, Taşnak ve Menşevik aydınlarının bu birliğe karşı çıkmada yalnız olmadığını iddia etmiştir (Akhundov, 1977:70). Ahundov, Musavat üyelerinin söylediği gibi, ZSRFR'nin kurulmasının bağımsızlığın yok edilmesi, ulusun haklarının ihlali anlamına gelmediğine kendisini ve kendisi gibi yerel Bolşevikleri ikna etmeye çalıştı.

Aksine, Cumhuriyet döneminde bağımsızlık biçimsel nitelikte olmuş, gerçek bağımsızlık ise Azerbaycan'da Sovyet iktidarının oluşturulmasıyla ortaya çıkmıştır. Ona göre Fransa, İngiltere ve diğer ülkeler, Azerbaycan, Gürcistan ve Ermenistan'ın birbirinden ve hepsinin Rusya'dan tamamen ayrılmasını talep ederek, güçleri bölmek ve Sovyet cumhuriyetlerini kolayca ortadan kaldırmak istiyorlardı (Akhundov, 1977:78). Ancak Sovyetler Birliği döneminde oluşturulan ZSFSR'nin de ömrü uzun sürmemiş ve 1936'da Güney Kafkasya'daki her ülke ayrı ayrı Sovyetler Birliği'ne üye olmuştur.

\section{SOVYETLER BİRLIĞİ'NİN DAĞILMASI VE BİRINCİ KARABAĞ SAVAŞI SIRASINDA DAĞLIK KARABAĞ SORUNU}

II. Dünya Savaşı'ndan sonra bile Ermeniler Azerbaycan topraklarını talep etmeye devam ettiler. Sovyet Hükümetinde, üst düzey bir yetkili olan A.Mikoyan'ın himayesinde "Karabağ Komitesi” oluşturuldu. 1945 yılının sonbaharında, Ermenistan yönetimi merkez karşısında Dağlık Karabağ'ın Azerbaycan'dan alınıp onlara verme konusunu gündeme getirmiştir. Azerbaycan Komünist Partisi Merkez Komitesi Birinci Sekreteri M. C. Bagirov nüfusun çoğunluğunun Azerbaycan Türklerinden oluşan Şuşa bölgesi dışında yukarı Karabağ'ın Ermenistan'a verilmesi ancak farklı dönemlerde Ermenistan'a, Rusya’ya ve Gürcüstan'a verilmiş olan tarihi topraklarımız bize geri iade edilecektir. Doğal olarak "Merkez" ve Ermeniler Bagirov'un teklifini kabul etmediler.

Bununla birlikte, Sovyet liderliği Ermeniler lehine bir dizi önlemler almıştır. SSCB Bakanlar Konseyi, 23 Aralık 1947 ve 10 Mart 1948 tarihlerinde, "Ermenistan SSR'den kolhozculartn ve diğer Azerbaycanlı nüfusun Azerbaycan SSR'in Kür-Araz ovasına yeniden yerleştirilmesi üzerine" kararnamelerle Azerbaycanlıların şimdi Ermenistan olarak adlandırılan arazideki (Batı Azerbaycan) ata topraklarından çıkarılması bir sonraki aşamanın başlangıcı olmuştur. Bu kararların uygulanması sonucunda Batı Azerbaycan'da yaşayan 150.000'den fazla Azerbaycanlı zorla kendi topraklarından çıkarılmışlarıdr. 1988 sonbaharında "Ulusal Uyanış Günü" gibi tarihte önemli olaylar yaşanmıştır.

Bakü'de yüzbinlerce Azerbaycanlı ve Azeri Türkünün katılımıyla Özgürlük Meydanında (eski adıyla Lenin Meydanı) mitingler sırasında önce Ermenilerin Dağlık Karabağla ilgili iddialarına itiraz eden halk kitleleri yavaş yavaş bağımsızlık talebinde bulunmuşlardır. Bu protesto gösterilerinde Azerbaycan Halk Cephesi (AHC) ve onun lideri Abulfez Elçibey de bu süreçlerde önemli rol oynamıştır (Yaqublu, 2018:11-15). Ancak Halk Cephesi Partisi ve halkın baskıları sonucu, Ermenistan'la savaşta başarısızlıklar, Hocalı katliamı (26 Şubat 1992) da dâhil olmak üzere başarısızlıkların bir sonucu olarak Mutallibov, Mart 1992'de devlet başkanlığından çıkarılmış ve başkanlık seçimlerine kadar Devlet Başkanı Yüksek Sovyet'in başkanlığını Yagub Memmedov tarafından yürütmüştür (5 Mart 1992 - 18 Mayıs 1992).

Şuşa'nın düşüşü ile 8 Mayıs 1992'de Ermeni-Rus askeri birlikleri tarafından Dağlık Karabağ bölgesinin işgali sona ermiştir. Bundan sonra aktif olan Mutallibovlar yasadışı bir şekilde iktidarı ele geçirmiş,14 Mayıs'ta yapılacak oylamayla başkanlık seçimlerinin iptal edildiğini ve A. Mutallibov'un görevine geri döndüğünü beyan etmiştir.

15 Mayıs'ta, Halk Cephesi Partisi genel merkezinde gösteri düzenlenmiş olup, burada A. Mutallibov'un başkanlık ikametgâhını terk etmesi talep edilmiştir. $\mathrm{O}$ da gizlice Moskova'ya kaçmak zorunda kalmıştır (Azerbaycan Tarihi, 2008c:305-306). Yüce Sovyet'in (Yüksek İstişare Kurulu) 18 May1s'taki bir sonraki oturumunda Y. Mammadov'un istifasının ardından Isa Gambar Yüksek Sovyet Devlet başkanı seçilmiştir. Ayrıca cumhurbaşkanlığı seçimlerine kadar cumhurbaşkanı sıfatını taşımıştır. O dönemde, Yüksek Sovyet Ulusal Konseyi "Milli Meclis" olarak adlandırılmış ve tüm yetkiler ona verilmiştir. Abulfez Elçibey 7 Haziran 1992 cumhurbaşkanlığ 1 seçimi sonucunda Ülkenin devlet başkanı seçilmiştir.

Elçibey yönetiminin ilk aylarında Sovyet-Rus birliklerinin ülkeden çıkarılması, ulusal para biriminin oluşturulması, eğitimde test yönteminin uygulanması Türk dili (Azerbaycan) devlet dili olarak adlandırılması için çalışmıştır. Ancak, cephede bazı ilerlemeler kaydetmesine rağmen (Azerbaycan Tarihi, 2008c:313-314), bu süreç uzun sürmemiştir. Böylece 1993 baharından bu yana cephede ciddi kayıpların olması, özellikle Nisan ayında Kelbecer'in işgalinden sonra Albay Surat Hüseynov'un Haziran ayında Gence'deki askeri ayaklanması 
sonucunda ülke içinde ve hükümette ciddi krizler yaşanmış ve çıkış yolu olarak Yeni Azerbaycan Partisi (YAP) başkanı, Nahçıvan Özerk Cumhuriyeti Yüksek Meclisinin başkanı, tanınmış siyasetçi, devlet adamı Haydar Aliyev'i Bakü'ye davet etmiştir (Azerbaycan Tarihi, 2008c:322).

9 Haziran'da Bakü'ye gelen Aliyev, isyancıların lideri Huseynov ile görüşmüştür. Ancak, Elçibey'in istifası talebinden geri adım atılmamıştır. 15 Haziran 1993'te Azerbaycan Cumhuriyeti Milli Meclisi, Haydar Aliyev'i Yüksek Sovyet başkanlığına seçmiştir. Bu esnada askeri isyancılar Bakü'ye doğru yola çıkmışlardır. Elçibey beklenmedik bir şekilde 17 Haziran'da Bakü'den ayrılarak Nahçivan'daki Keleki köyüne gitmiştir. Ülkenin yönetimi yani cumhurbaşkanının yetkilerinin uygulanması ve Yüksek Sovyet başkanı gibi görevler Aliyev'in üzerine kalmıştır (Azerbaycan Tarihi, 2008c:323). Kısa bir süre sonra yapılan referandum sonucunda (29 Ağustos 1993) Elçibey’in Başkanlık görevine son verilmiştir.

Olağanüstü cumhurbaşkanlığı seçimi 3 Ekim 1993'te yapılmıştır. Seçim sonucunda Haydar Aliyev ülkenin yeni devlet başkanı seçilmiştir. Haydar Aliyev'in devlet başkanlığına seçilmesinin ardından öncelikle ülkede istikrar sağlanmıştır. Ülke içindeki tüm ayrılıkçı güçler etkisiz hale getirilmiştir. 8 Mayıs 1994'te Ermenistan ile Azerbaycan arasında Bişkek Protokolü yani ateşkes imzalanmıştır.

Azerbaycan Cumhuriyeti'nin tek özerk bölgesi olan "Dağlık Karabağ" ile birlikte aynı zamanda 7 rayon (Laçin, Kelbecer, Ağdam, Fuzuli, Cebrayıl, Zangilan ve Gubadli) de Rus-Ermeni askeri birlikleri tarafindan işgal edilmiştir. BM Güvenlik Konseyi, bu toprakların işgalden derhal kurtarılması için dört karar kabul etmesine rağmen Eylül 2020'ye kadar bunun her hangi bir etkisi olmamıştır.

Özellikle 20. yüzyılda Azerbaycan ve Ermeni halkları arasında yaşanan çatışmalar, 1905-1906 yıllarındaki Ermeni-Müslüman ihtilafları, 30-31 Mart Azerbaycan Türklerinin soykırımı, 1920'de Zangazur'un Ermenistan'a verilmesi ve Dağlık Karabağ Cumhuriyeti'nin oluşturulması da dâhil olmak üzere, 1948-1953'te bugünkü Ermenistan'dan yüzbinlerce Azerbaycanlının topraklarından sürülmesi, 26 Şubat'ta Hocalı soykırımının yaşanması ve 1988-1994 yılları arasında Dağlık Karabağ ile diğer yedi bölgenin işgali, Karabağ sorununa karşı savaşı kaçınılmaz hale getirmiştir.

Azerbaycan halkına yönelik bu soykırımlarda Rus milliyetçileri ve Ermeni şovenistler önemli rol oynamışlardır. Her halükarda, Rusya ve Rus askerleri olmadan Ermenilerin Azerbaycan-Türk soykırımını tek başlarına yapamayacakları asla unutulmamalıdır. Öyleyse, bu soykırımların özü derinlemesine anlaşılmalı ve doğru sonuçlar çıkarılmalıdır. Yaşanan soykırımlarda sadece Ermenilerin ve Ermenistan'ın değil, Rusya'nın da büyük bir paya sahip olduğu unutulmamalıdır.

Bir zamanlar Azerbaycan'ın bazı bölgelerinde Ermeni devleti kuran Rusya'nın, son zamanlarda Azerbaycan topraklarının başka bir kısmının işgalinde aktif rol oynadığı ve ikinci bir sahte "Ermeni devleti" kurma hayali ile ikiyüzlü politika izlediği bir gerçektir. Üstelik Rusya tarafından her zaman hibe edilen silahlarla Ermenistan'ın bölgede barışa "sıcak" yaklaşmasını beklemekte imkânsızdır. Bu gerçeklik, kısa ömürlü olan 2016 Nisan dönemi muharebesinde bir kez daha kanıtlanmıştır. Rusya, Nisan savaşlarında önemli askeri başarılar elde eden Azerbaycan ordusunun askeri operasyonlarını durdurmak için elinden geleni yapmış ve de bunu başarmıştır.

\section{KARABAĞ VATAN SAVAŞI VE DAĞLIK KARABAĞ SORUNUYLA İLGILİ YENİ KOŞULLAR}

27 Eylül - 9 Kasım 2020, Azerbaycan halkının kaderinde yeni bir aşamadır. İşgal altındaki toprakların her ne pahasına olursa olsun geri alınması için yapılmış bir kurtarma savaşıdır. Yapılan mücadele, İkinci Karabağ Vatan Savaşıdır. Bu dönemde Azerbaycan ordusunun tek bir amacı vardı. Ermenistan ile devlet sınırlarını yeniden kurmak ve sınırları içindeki tüm Ermeni terörist ve taraftarlarını temizlemek. Azerbaycan halkı, 30 yılı aşkın bir tecrübeye dayanarak, İkinci Karabağ Savaşı'nda hangi ülkelerin dost ve hangi ülkelerin karşıt söylem ve politikalar yürüteceğini bilerek stratejilerini oluşturmuştur. Türkiye ve Pakistan başta olmak üzere Azerbaycan'ın haklılığını vurgulayan az sayıda ülke açıklamalarda bulunmuştur. Dünya kamuoyundan genel olarak itidal çağrıları yapılsa da kesin barışın temini için gerekli olan Ermenistan'ın işgallerini sona erdirmesi yönünde pek fazla çağrılara rastlanılmamıştır. Bu bağlamda sahada fiili ve fiziki olarak Azerbaycan'a destek sağlanması da çok sınırlı düzeyde gerçekleşmiştir. Azerbaycan yanında yer alan az sayıdaki devletlerin desteklerinin ölçüsü de elbette farklı düzeylerde söz konusu olmuştur. Bu kapsamda Vatan Savaş'nda tek millet (Türk), iki devlet (Azerbaycan + Türkiye) olarak kabul dilen Türkiye ve Azerbaycan ortak bir duruş sergilemişlerdir. Savaşın ilk gününden son anına kadar, Türkiye Azerbaycan'ı tartışmasız ve şartsız olarak destek vermiştir. Türkiye Dışişleri Bakanı Mevlüt Çavuşoğlu başta olmak üzere birçok üst yetkilinin ilgili süreçte Azerbaycan'ı defalarca ziyaret etmesi tesadüfî bir durum değildir. Yaşanan bu gelişmeler, Azerbaycan'a 
siyasi ve manevi destek sağlayan Türkiye'nin de Karabağ'1 işgalden kurtarmak için en üst ve Azerbaycan'a eşit derecede istekli olduğunu göstermektedir.

İkinci Karabağ Savaşı'nda şüphesiz Türkiye ile birlikte Pakistan da Azerbaycan'ın en büyük siyasi ve manevi destekçisi olmuştur. Bu bağlamda, Türkiye ve Pakistan'ın Azerbaycan'a verdiği destek, Azerbaycan halkının anısında sonsuza kadar yaşayacağını tahmin etmek zor değildir. Aynı zamanda Kuzey Kıbrıs Türk Cumhuriyeti, Ukrayna, İsrail, Moldova, Bosna Hersek, Gürcistan ve diğer bazı ülkeler de bu savaşta Azerbaycan'ı destekleyen ülkeler arasında yer almışlardır.

Fransa, Yunanistan, Güney Kıbrıs, Birleşik Arap Emirlikleri, İran, Rusya, Hollanda ve diğer bazı ülkeler İkinci Karabağ Savaşı'nda doğrudan ya da dolaylı olarak Ermenistan'ı desteklemşlerdir. Özellikle savaş sırasında Fransa Cumhurbaşkanı Macron ve bir grup Fransız milletvekili Erivan'a giderek destek olmuşlardır. Bu durum, Fransa'nın AGİT Minsk Grubu eşbaşkanı olamayacağını bir kez daha göstermiştir. Üstelik savaştan sonra Fransız Senatosu ve Parlamenterler Meclisi'nin sözde "Dağlık Karabă̆" rejimini tanıma kararları almaları da mevcut durumu bir kez daha gözler önüne sermiştir. Fransız hükümetinin Fransız senatörlerin ve parlamenterlerin verdiği kararların kabul edilemez olduğunu ve bunu tanımadığını söylemiştir. Bununla birlikte, her durumda, Fransa'nın yanlı tutumu, Paris'teki Karabağ ihtilafında Ermeni yanlısı tarafını açıça ortaya koymuştur.

Genel olarak, savaş sırasında AGíT Minsk Grubu eşbaşkanlarının (Rusya, Fransa ve ABD) farklı pozisyonları, özellikle Fransa'nın açıklığı ve Rusya'nın Ermenistan'a dolaylı desteği bir kez daha ortaya çıkmıştır. Amerika Birleşik Devletleri ise hala çifte standartlarıyla hatırlanıyor. Bu, AGIT Minsk Grubu'nun faaliyetlerini askıya almaktan başka bir yol olmadığı anlamına geliyordu. Dağlık Karabağ meselesinde zaten iki gerçek aktif güç vardı: Türkiye ve Rusya.

Savaş sırasında İran'ın çift taraflı eylemlerine defalarca tanık olunmuştur. Molla-Fars rejimi, dolaylı da olsa, Azerbaycan'ın kurtardığı topraklarda bazı terörist grupların olduğunu iddia etmiştir. İlginçtir ki, savaştan önce Ermenistan'ın saldırgan, ayrılıkçı rejimini terörist olarak değil, savaş sırasında Azerbaycan ordusunun kurtardığı bölgede terör örgütü arayan İran olmuştur. Ne yazık ki İran, Birinci Karabağ Savaşı'nda olduğu gibi İkinci Karabağ Savaşı'nda da açık olmasa da dolaylı olarak Ermenistan'a askeri yardım sağlamıştır. Ancak savaşın sonuna doğru resmi Tahran, Azerbaycan'ın toprak bütünlüğünün tanınması konusunda en üst düzeyde açıklamalar yapmıştır. Ancak İran'ın bugüne kadar Ermenistan'ın yanında yer alması ve bunun birleşik Azerbaycan fikrinin gerçekleşmesi tehdidinden kaynaklanıyor olması bilinen bir konuydu.

Rusya İkinci Karabağ Savaşı'nda masumane bir tavır sergilerken, esasen Ermenistan'ın yanında yer almıştır. Bununla birlikte Rusya Devlet Başkanı Viladimir Putin, Dağlık Karabağ'ın Azerbaycan toprağı olduğu yönünde de açıklamalar yapmıştır. Bunun yanı sıra Rusya Dışişleri Bakanı Sergey Lavrov'un tüm tarafların rızası ile Rus ordusunun çatışma bölgesine, yani Dağlık Karabağ'da barışı koruma görevlisi olarak gelebileceğini ima etmesi tesadüfî değildir. Azerbaycan halkı Azerbaycan'da bir daha Rus askerlerini görmek istemese de Lavrov'un açıklaması sonunda bağımsız Azerbaycan'da Rus askerlerininin bulunması gerçekleşmiştir. Rusya'nın Karabağ sorununun barışç1l çözümüne daha yüksek bir katılım biçimi göstermemesi oldukça ilginçtir. Çünkü 10 Kasım'da yayınlanan üçlü açıklamada Türkiye'den bahsedilmemiştir. Sadece bölgede bir Barışı Koruma İzleme Merkezi'nin varlığından ve dolayısıyla Türkiye'nin orada bulunma ihtimalinden bahsediliyordu. Dolayısıyla savaş sırasında Azerbaycan'ın cephede başarılı yürüyüşüne devam edebilmek için Anavatan, Milli Birlik, Azerbaycan'ımızın bütünlüğünden bahsediyorsak sabırlı ve ölçülü olmamız gerektiğine inandık. Her halükarda, hepimiz Şuşa, Hankendi ve Laçin'in kurtuluşu için verilen mücadele ve mücadelenin boyutunu iyi anladik. Özellikle, işgal altındaki Dağlık Karabağ'da bulunan ayrılıkçı rejim liderlerinin 4 Kasım'da Hankendi'den Erivan'a kaçmaları tesadüf değildi. Bu olay her an Şuşa ve Hankendi'nin Azerbaycan ordusu tarafindan kurtarılacağını ortaya koymuştur.

Azerbaycan Savunma Bakanlığı'nın 7 Kasım'da verdiği bilgi (Azerbaycan Ordusu Şuşa şehrine ateş açmadı) oldukça ilginçtir. Bakanlık aslında Şuşa kentinde çatışmaların devam ettiği ve büyük ölçüde Azerbaycan askerinin kontrolünde olduğu bir dönemde Azerbaycan ordusunun kendisine uzaktan ateş etmesine gerek olmadığını söylemek istemiştir. Nitekim 8 Kasım'da Cumhurbaşkanı İlham Aliyev, Şuşa'nın işgalden kurtarıldığını halka duyurdu. Ancak Azerbaycan, Ermenistan ve Rusya'nın 9-10 Kasım gecesi yaptığı ortak açıklama, Ermenistan'ın yenilgiyle uzlaştı̆̆ını ifade ederken, Rus barış güçlerinin Dağlık Karabağ'a gelişini de yansitıyordu ( $5+5$ yıllık bir süre için). Azerbaycan halkının çoğunluğu Ağdam, Kelbecer ve Laçin bölgelerinin barışçıl tahliyesinden ve Nahçıvan ile Zangilan arasında bir koridorun varlığından memnunken (bu yönde henüz yeni bir şey yok), Ayrılıkçı lider Arayik Harutyunyan ile görüşmeler yapmaktan ve en önemlisi, Hankendi, 
Ağdara, Khosavand ve eski Dağlık Karabağ Cumhuriyeti'nin Azerbaycan ordusu tarafindan kurtarılmayan diğer bölgelerinin Ermeni kontrolü altında kalmasından ciddi endişe duydular.

Azerbaycan Cumhurbaşkanı İlham Aliyev konuşmalarında sözde Dağlık Karabağ sorununun bittiğini ve ancak tarihsel anlamda kullanılabileceğini söyledi. Bu sözler Cumhurbaşkanı İlham Aliyev tarafından 10 Aralık 2020'de Bakü'nün Özgürlük Meydanı'ndaki Zafer Geçit Töreninde tekrarlandı. Zafer Geçit Töreni'ne de katılan Türkiye Cumhurbaşkanı Recep Tayyip Erdoğan, Karabağ'ın çoktan kurtarıldığını ve anayurdun Azerbaycan ile yeniden birleştiğini söyledi. Ancak asıl etken, iki cumhurbaşkanının Karabağ'ın kurtuluşu ve Azerbaycan ile yeniden birleşmesinden söz ederken, halen Rus barış güçlerinin kontrolü altında olan Hankendi de dâhil olmak üzere Ermenilerin yaşadığı Dağlık Karabağ bölgesinden bahsetmemeleriydi.

Genel olarak en ilginç detaylardan biri, Bakü ve Ankara'nın şu anda Rus barış güçleri tarafından kontrol edilen Dağlık Karabağ'daki ayrılıkçıların rahat hareketi konusunda sessiz kalmayı tercih etmeleri, ayrılıkçı liderin "ikametgâhında" toplantılar ve "randevular" düzenlemeleri, ayrıca Ermenistan ile Dağlık Karabağ arasındaki Laçin koridorunun 5 kilometre genişliğinde bir alan içinde olması ciddi bir endişe kaynăğdır. Öte yandan birçok olay, Ermenistan silahlı kuvvetlerinin Dağlık Karabağ bölgesinden tamamen temizlenmediğini gösteriyor. Dahası, Ermeni teröristler Rus barış koruma görevlilerinin peşine düşerek mevcut iletişim hatlarını güçlendirmeye çalışıyorlar. Burada dikkat edilmesi gereken temel noktalardan biri, Dağlık Karabağ bölgesinde hala bir temas hattının ve ateşkes denen bir kavramın var olmasıdır. Özellikle 26 Kasım, 8 Aralık ve 12 Aralık 2020 tarihlerinde Ermeni teröristler, Hadrut kasabası yakınlarındaki Hocavend ilçesine bağlı Sur köyünde Azerbaycan askerlerini öldürmeleri endişelerin haklı olduğunu göstermektedir. Öte yandan 8-12 Aralık olayları da 10 Kasım üçlü açıklamasının ardından ciddi ateşkes ihlalleri olarak görülüyor.

Azerbaycan askerinin kendi topraklarındaki teröristleri temizlemeye devam etmesi ateşkesin ihlali olarak değil, teröristlerin imhası olarak görülmelidir. Azerbaycan Savunma Bakanlığı ve Devlet Güvenlik Teşkilatı'nın ortak açıklaması 13 Aralık'ta yayınlandı. Raporda ayrıca Rus barış güçlerinin Azerbaycan ile Ermeni teröristleri kovmak için çalışmasına rağmen, sadece bazı Ermeni teröristlerin Azerbaycan topraklarından çıkmak yerine terörizme giriştiği belirtiliyor. Rapora göre, Ermeni terörü sonucu dört Azerbaycan askeri öldürüldü ve Azerbaycan Cumhuriyeti Devlet Güvenlik Servisi Hocavend bölgesinde terörle mücadele operasyonu yapmak zorunda kaldı. Raporda ayrıca, Ermeni tarafının üçlü bildirgenin hükümlerinin uygulanmasını sağlaması, ateşkes ve barışın sürdürülmesine destek olması, kalan Ermeni silahlı kuvvetleri veya Ermeni silahlı kuvvetlerinin kalıntıları aracılığıyla provokasyon yapmaktan kaçınması gerektiği belirtiliyor. Ancak görünen o ki, Azerbaycan hükümeti Dağlık Karabağ'ın Ermeni nüfuslu bölgelerinde kurulmadığı ve Rus barışı koruma görevlilerinin kontrolü altında olmadığı sürece bu tür pek çok "ateşkes" ihlali yaşanacaktır. Genel olarak Azerbaycan topraklarında "ateşkes" kavramı kabul edilemez. Tek çıkış yolu Laçin koridorunu kapatmak ve şu anda Dağlık Karabağ'daki Rus barış güçlerinin kontrolünde olan Khankendi, Hocalı, Askeran, Hocavend ve Ağdara'da Azerbaycan bayrağını dalgalandırmaktır.

Laçin koridoru kapalı olmadığı ve Rus barışı koruma görevlileri (barış gücü olarak adlandırılabilirlerse) Dağlık Karabağ'ı terk etmedikleri sürece, Azerbaycan'ın Birleşmiş Milletler tarafından tanınan topraklarda egemenlik gücünü tam olarak kurması mümkün olmayacaktır. Her halükarda, İkinci Karabağ Savaşı'nda 2.783 kişiyi öldüren ve binlerce gazisi bulunan Azerbaycan, nihayetinde toprak bütünlüğünü tam anlamıyla sağlamak zorundadir.

Azerbaycan'da bir Türk askeri üssünün varlığının, Azerbaycan'ın toprak bütünlüğünün tam anlamıyla gerçekleşmesinde çok önemli bir rol oynayacağı beklenebilir. Türkiye, şu ana kadar, üçlü bir açıklamaya göre Dağlık Karabağ bölgesindeki Barışı Koruma İzleme Merkezine gözlemci olarak katılacaktır. Dağlık Karabağ'a Türk askeri gönderilmesi belgesi de 4 partiden (AKP, CHP, MHP) üç parti milletvekillerinin oy birliğiyle Meclis tarafindan da onaylandı. İlk aşamada Türk birlikleri bir yıllığına Azerbaycan'da olacak ve Dağlık Karabağ'daki ateşkesi izlemek için Rusya ile birlikte Barışı Koruma İzleme Merkezine katılacak. Bu durumda ilk beklenti Türk birliklerinin Barışı Koruma İzleme Merkezinde olması ve süreci yakından takip etmeleridir. Her halükarda, Türkiye'nin sadece Dağlık Karabağ'ın aslında kendi kontrolü altında olmayan, Azerbaycan'a ait olan bölümünde olup bitenleri yakından izleyeceğini ve Azerbaycan hükümetinin bu topraklarda tam istikrarına katkıda bulunacağı beklenmektedir. Bunun için Azerbaycan ile Türkiye arasında kısa sürede askeri bir anlaşma yapılması ve Azerbaycan'da bir Türk askeri üssü konuşlandırılması gerekmektedir. 


\section{SONUÇ}

Ermenilerin, Türkler ile ilgili "düşman olma" imajını oluşturmak için Azerbaycan Türkleri de dâhil olmak üzere Türk halklarına karşı bir araç olarak kullanılması son iki yüzyılın bir ürünüdür. Rusya, İngiltere, Fransa ve diğer Avrupa ülkeleri ile ideologları da bu konuda önemli rol oynamışlardır. Nitekim Ermeniler ile Azerbaycan Türkleri de dâhil olmak üzere tüm Türk halkları arasındaki "tarihi düşmanlık" 19. yüzyılın başlarında bu devletlerin (özellikle de Rusya ve Büyük Britanya'nın) "Büyük Ermenistan" oyunuyla ortaya çıkmış ve günümüze kadar devam etmiştir.

Türkler ile Ermeniler arasında oluşturulan "tarihi düşmanlık" nedeniyle yapay olarak gündeme getirilen Dağlık Karabağ sorunu her iki ülkenin de gerek iç politika ve gerekse dış politikasını şekillendiren hassas ve kritik bir unsurdur. Uluslar tarafından oluşturulan tarihsel düşmanlıklar ve düşmanca kurgular komşuluk hukukuna ve toplumsal barışa her zaman zarar verecektir. Buradan hareketle Ermenistan'in hakk1 olmayan topraklar üzerindeki iddialarından ve yine gerçek olmayan soykırım iddialarından vazgeçerek gerçek ve uygulanabilir politikalar üretmesi zorunludur. Komşuları ile sıcak ya da soğuk savaşın içinde bulunan devletlerin ekonomik olarak gelişmeleri, bütçe harcamalarını optimal bir ölçekte gerçekleştirmeleri, stratejik yatırımlar yapmaları oldukça güçtür. Kendi geleceğini tesis etmek yerine, küresel güçlerin stratejileri için bir araç olmayı tercih etmek Ermenistan için başarının değil, hüsranın kapılarını açacaktır.

Mevcut konumu ve yaşanan tarihsel süreç dikkate alındığında Ermeni liderliğinin ve radikal şovenist çevrelerin (taşnaktsutyun vb.) Azerbaycan Türkleri ve Gürcülere karşı toprak ve kültürel anıt iddialarından acilen vazgeçmesi gerekmektedir. Özellikle Rusya ve diğer Batılı ülkelerin himayesinde son iki asırdır Kafkasya'da barışı bozan Ermeniler, bunun bu şekilde devam etmeyeceğini, ilgili devletlerin gerekirse güç kullanarak bu tacizlere karşılık vereceğini fark etmelidir. Hiç şüphesiz yaşanan son gelişmeler bunun en önemli delili ve örneğidir. Aksi durumda patronlarını kaybeden Ermenilerin komşu milletlerle birlikte yaşaması imkânsız olacaktır. Bu sebeple Ermeniler, 44 günlük İkinci Karabağ Savaşı'ndan ciddi bir ders çıkarmalı ve Kafkasya politikalarını tekrar gözden geçirmelidir. Özellikle Azerbaycan Türklerini tarihi bir düşman olarak görmek yerine başta ekonomik gelişme olmak üzere ülkelerinin geleceği için gerekli olan bir müttefik olarak kabul etmeleri elzemdir. Bunu gerçekleştirmek içn de öncelikle uzun yıllardır sürdürdüğü düşmanca tavırlarına son vermeli ve sebep olduğu zararları tazmin etmelidir. Başlangıç olarak ta doğrudan ya da dolaylı olarak dâhil olduğu eylemlerinden dolayı (Mart 1918 soykırımı, Hocalı soykırımı, 26 Şubat 1992 vb.) resmi olarak özür dilemelidir. $\mathrm{Bu}$ bağlamda haklarında verilecek uluslararası yaptırımları kabul ederek, ilgililerine maddi ve manevi açıdan tazminat ödemelidir. En önemlisi de bir daha bu bağlamda herhangi bir eylem ya da politika içerisinde olmayacağını teminat altına almalıdır.

Ermenilerin Azerbaycan ve Doğu Anadolu'daki Müslüman-Türk nüfusa karşı işledikleri soykırım, Ermeni hastalığının ve vahşetinin "tarihsel hafızasının" yüzüdür. Bu sadece sözde Ermeni soykırımından önce komşu Türklerden intikam aldığına inanan bir milletin görüşü değil, aynı zamanda hamisi Rusya'nın ve Batı'nın şovenist çevrelerinin Azerbaycan halkına karşı düşmanca tavrının da açık bir örneğidir. Her halükarda, geçen yüzyılda Azerbaycan halkının başına gelen trajik olaylardan, yani Ermenilerin Müslüman-Türk nüfusa karşı gerçekleştirdiği soykırımdan Batı ve Rusya'nın bir ölçüde sorumlu olduğu yadsınamaz bir gerçektir. Azerbaycan Türkleri de bu acımasız tarihi derslerinden, özellikle soykırım gerçeklerini öğrenmelidir. Bu bağlamda dostlarını ve düşmanlarını daha iyi tanımalıdır. Kuşkusuz Rus şovenistleri ve Fransız radikal milliyetçileri, Ermeni şovenistlerinin yanı sıra Azerbaycan halkına yönelik bu soykırımlarda önemli rol oynadılar.

Bazı Batı ülkeleri ve Rusya desteği olmadan Ermenilerin Türk-Müslüman soykırımını tek başlarına gerçekleştirmeleri ve Azerbaycan topraklarını uzun süre işgal etmeleri mümkün değildir. Bu sebeple yapılan soykırımlarda sadece Ermenilerin ve Ermenistan'ın değil, Rusya ve Batı'ın da büyük bir payı olduğu unutulmamalıdır. Bir zamanlar Azerbaycan'ın bazı bölgelerinde Ermeni devletini kuran Rusya ve Batı'nın, son zamanlarda Dağlık Karabă̆'ın işgalinde aktif rol oynadıkları ve ikinci bir yapay "Ermeni devleti" kurmak için ikiyüzlü bir politika izledikleri yadsınamaz bir gerçektir. Ancak muzaffer Azerbaycan ordusunun 44 günlük İkinci Karabağ Vatan Savaşı sonucunda sözde "Dağlık Karabă̆" rejimi yıkılmıştır.

Ermeniler hala Dağlık Karabağ'ın belli bir bölgesinde (Khankendi, Hocalı, Hocavend, Ağdara, Askeran) Rus barış güçlerinin himayesi altında yaşamaktadırlar. Orta ve uzun vadede bu varlığın devamı Azerbaycan için bir tehdit, Ermeniler için de boş bir hayal ve barışı bozma vesilesi olacaktır. Bu nedenle Dağlık Karabağ' da hiçbir Ermeni yerleşkesinin bağımsız ve bütün bir şekilde iskânına izin verilmemelidir. Fiili ve fiziki açıdan varlıkları sonlandırılmayan Ermeni unsurlar uzun vadede tekrar yayılmac1 bir politika sergileyebilecekleri unutulmamalıdır. 
Yaşanan tarihi zafer ve yürütlen etkin politikalar neticesinde Dağlık Karabağ tekrardan fiilen bir Azerbaycan yurdu haline gelmiştir. Azerbaycan askeri güçlerinin yanı sıra kamu kurumlarının ve yerel halkın yeniden buralardaki iskânı ile birlikte bu topraklar olması gerektiği gibi gerçek anlamda bir Türk yurdu haline gelecektir. Buralarda yuvalanmaya çalışan Ermeni teröristler kesin bir şekilde etkisiz hale getirilerek, Azerbaycan hukuku altında hesap vereceklerdir.

Kısa bir süre içinde Hankendi dâhil Dağllk Karabağ'ın tüm bölgelerinde Azerbaycan hükümeti yeniden kurulacak, Azerbaycanlılar ana topraklarına dönüp burada yaşayacaklardır. Kısacası, Dağlık Karabağ sorununun gerçekten de tarih arşivlerine atıldığına inanılmak istenilmektedir. Bununla birlikte, Laçin koridorunun varlığı, sözde rejim dokusunun Hankendi'de hala dalgalı olduğu gerçeği, ayrılıkçıların adalete teslim edilmemesi ve çoğu durumda Rus barış gücünün ayrılıkçıları savunmak için hareket etmesi gibi sebeplerle üçüncü bir Karabağ savaşı olasılığı tamamen göz ardı edilemez. Bu sebeple Azerbaycan devletinin başta Pakistan ve Türkiye olmak üzere gerçek müttefikleri ile daha yakın ve güçlü ilişkiler kurarak bu tehdide karş1 güçlü bir blok oluşturması gerekmektedir. Kurulan ve çok önemli başarılar elde eden bu tarihi blok, sadece Karabağ'ın değil, Kafkasya'nın da geleceği açısından stratejik bir öneme sahiptir.

\section{KAYNAKLAR}

AFSHAR, Nadir Şah (2015), Diplomatik Yazışmalar, Doğu - Batı Yayınevi, Bakü.

AĞAOĞLU, Ahmed (2019), Kafkasya'da Ulusal Bir Mesele, Çevirmen Yayınevi, Bakü.

AĞAOĞLU, Ahmed (1905), “Bakü'deki Olaylar Hakkındaki Gerçek”, St. Petersburg Gazetesi, 21-22 Nisan 1905, S.123.

AKGÜNDÜZ, Ahmet ve ÖZTÜRK, Said (2008), Soruları Olan Ermeni Meselesi, Pasifik Ofset, İstanbul.

AXUNDOV, Ruhulla (1977), Seçilmiş İşler, Azerneshr Yayınevi, Bakü.

ALAKBAROV, Faiq (2011), Ulusal İdeoloji Sorununa Tarihsel ve Felsefi Bakış, Taknur Yayınevi, Bakü.

AZERBAYCAN EDEBIYYATI (2009), 19. Yüzyıl Azerbaycan Edebiyatı, Nurlar Yayınevi, Bakü, C.1.

AZERBAYCAN TARİHI (2007a), Azerbaycan Tarihi, Bilim Yayınevi, Bakü, C.3.

AZERBAYCAN TARİHI (2007b), Azerbaycan Tarihi, Bilim Yayınevi, Bakü, C.4.

AZERBAYCAN TARİHI (2008a), Azerbaycan Tarihi, Bilim Yayınevi, Bakü, C.5.

AZERBAYCAN TARİHi (2008b), Azerbaycan Tarihi, Bilim Yayınevi, Bakü, C.6.

AZERBAYCAN TARİHI (2008c), Azerbaycan Tarihi, Bilim Yayınevi, Bakü, C.7.

BAKIKHANOV, Abbasgulu Ağa (2001), Gulustani-Iram, Momin Yayınevi, Bakü.

BALAEV, Aiden (1992), Azerbaycan Milli Hareketi 1917-1918, Elm Yayınları, Bakü.

BALAYEV, Aydın (2011), Mammad Amin Resulzade (1884-1955), Çırağ Yayınevi, Bakü.

BAYKARA, Hüseyin (1992), Azerbaycan'ın Bağımsızlık Mücadelesinin Tarihi, Azerneshr Yayınevi, Bakü.

CAVAD, Ahmed (2005), Seçilmiş Eserler, Doğu - Batı Yayınevi, Bakü.

ELEKBERLİ, Faik (2017), Turan Medeniyetine Giriş: Turan İdeolojisi ve İlahiyat, Han Yayınevi, Bakü.

FATALI, Khan Khoyski (1998), Yaşam ve Aktivite (Belgeler ve Malzemeler), Azerbaycan Yayınevi, Bakü.

GARABAGHNAMES (2006a), Rezervasyon Yaparım, Doğu - Batı Yazlık, Bakü.

GARABAGHNAMES (2006b), Kitap II. Bakü, Doğu - Batı Yazlık, Bakü.

GÜLIYEV, Jamil (1957), Lenin ve Azerbaycan'da Sovyet İktidarının Zaferi ve Sağlamlaştırılması İçin Mücadele, Azerneshr Yayınevi, Bakü.

HASANZADE, Tahira (2007), XVIII-XIX Yüzyıllarda İran'da Yaşayan Azerbaycanlı Sosyo-Politik Figürler, Bilim ve Eğitim Yayınevi, Bakü.

HÜSEYNZADE, Ali Bey (1905), Ermeni Vatandaşlarımıza Tavsiyemiz ve İcadımız, Hayat gazetesi, №21, Bakü. 
İBRAHIM, Halil (1917), “Savaş ve Kadın”, "Kardeş Yardım" Jüri., Mayıs, №1, Bakü.

JAFAROV, Memmed Yusif (1917), "Müslüman Askerlere ve Müslüman Avukatlara Yardım", "Kardeş Yardım" Jüri., Mayıs, №1, Bakü.

KAHRAMAN, Nazif (2008), Nasib Bey Örneği, Nurlan Yayınevi, Bakü.

KOÇERLİ, Firudin Bey (1917), "Hayvanlar ve İnsanlar”, "Kardeşçe Yardım" Jüri., Mayıs, №1, Bakü.

MALIKZADE, Tohid Dilmagani (2010), Birinci Dünya Savaşı Sırasında Güney Azerbaycan - Soykırım, Bakü Matbaas1, Bakü.

MAMMADOV, İsmail (2005), Azerbaycan Tarihi, Adiloğlu Yayınevi, Bakü.

MAMMADZADE, Mirza Bala (2007), Köylü Hareketi: Lenin'in Ulusal Politikası, Bilim ve Eğitim Yayınevi, Bakü.

NAJAFOV, Halil (1966), Samedağa Ağamalıŏlu, Azernşar Yayınevi, Bakü.

NASIBLI, Nasib (2013), Güney - Kuzey Sorunlarımız, Crescent-3 Yayınevi, Bakü.

NASIROV, Tahir (1993), Azerbaycan'da İktidar Mücadelesi (1917-1920), Azerbaycan Yayınevi, Bakü.

NAVVAB, Mir Mohsun (2006), İşler, Doğu - Batı Yayınevi, Bakü.

NEMANZADE, Omar Faiq (2006), Seçilmiş Eserler, Doğu - Batı Yayınevi, Bakü.

NIGARI, Mir Hamza Seyid (2012), Nigarname, Bilim Ve Eğitim Yayınevi, Bakü.

PAKRAVAN, Amina (2007), Abbas Mirza ve Azerbaycan, Qanun Yayınevi, Bakü.

RASULZADE, Mohammad Amin (1916), “Türkiye'deki Ermeniler”, Açık Kelime Gazetesi, №259, 15.08.1916, Bakü.

RASULZADE, Mohammad Amin (1990), Azerbaycan Cumhuriyeti, Elm Yayınevi Yayınları, Bakü.

RASULZADE, Mohammad Amin (2001), İşler, Azerneşr Yayınevi, Bakü, C.1.

RASULZADE, Mohammad Amin (2001), İşler, Şirvanneşr Yayınevi, Bakü, C.2.

RASULZADE, Mohammad Amin (2009), Ulusal Birlik, Çıră̆ Yayınevi, Bakü.

RASUlZADE, Mohammad Amin (2012), Panturanizm: Kafkasya Sorunu, Taknur Yayınevi Yayınları, Bakü.

REZA, Azeri (1379), Staff-E Olağanüstü-Siz Kafkasya, Rezaiya Yayınları, Tahran.

SAFARI, Hasan (2016), Güney Azerbaycan: 1918 Bir Soykırım Mı?, Araz Yayınevi, Bakü.

SALADDIN, Ali (1992), Ahmad Javad, Gençlik Yayınevi, Bakü.

SUlTANOV, Khosrov Bey (1917), “Bakü Müslüman Yardım Derneği Askeri Yardım Departmanının Faaliyetleri”, Kardeş Yardım Jüri, Mayıs, Bakü, №1.

SVYATOKHOVSKY, Tadeusz (1990), Rus Azerbaycan 1905-1920, Vaku, Hazar.

TOPÇUBAŞI, Ali Mardan (2013), Azerbaycan Cumhuriyeti'nin Kuruluşu, Taknur Yayınevi, Bakü.

VAKILOV, Rüstam (1998), Azerbaycan Cumhuriyeti Tarihi, Bilim Yayınevi, Bakü.

YAGUBLU, Nasiman (2018), Azerbaycan Ulusal Özgürlük Hareketi Ansiklopedisi, Hukuk Yayınevi, Bakü.

ZAKIR, Gasim Bey (2005), Seçilmiş İşler, Avrasya Basın Yayınevi, Bakü.

ZARDABI, Hasan Bey (2005), Çiftçi: 1875-1877, Avrasya-Basın Yayınevi, Bakü. 